\title{
Article
}

\section{Research Institutes in Poland as an Element of the National Innovation System-Complexity, Financing and Effectiveness}

\author{
Izabela Jonek-Kowalska
}

check for

updates

Citation: Jonek-Kowalska, I Research Institutes in Poland as an Element of the National Innovation System-Complexity, Financing and Effectiveness. J. Open Innov. Technol. Mark. Complex. 2021, 7, 162. https:// doi.org/10.3390/joitmc7020162

Received: 27 April 2021

Accepted: 18 June 2021

Published: 21 June 2021

Publisher's Note: MDPI stays neutral with regard to jurisdictional claims in published maps and institutional affiliations.

Copyright: (C) 2021 by the author. Licensee MDPI, Basel, Switzerland. This article is an open access article distributed under the terms and conditions of the Creative Commons Attribution (CC BY) license (https:/ / creativecommons.org/licenses/by/ $4.0 /)$.
Faculty of Organization and Management, Silesian University of Technology, 44-100 Gliwice, Poland; Izabela.Jonek-Kowalska@polsl.pl

\begin{abstract}
Transfer and diffusion of knowledge and technology is a key condition for the development of innovation. In practice, they take place at the interface between science and business, which makes the level of innovation and development of a given economy depend on the effectiveness and efficiency of universities and other scientific units co-creating the national innovation network. With this important circumstance in mind, this article presents an assessment of the operations of selected research institutes in Poland in 2014-2019 in the context of pro-efficiency statutory changes aimed at making the commercialization of research and development results more effective. The multiple case study used in the article includes five units operating in the field of environmental protection (two) and energy (three)—sectors relevant to the transformation of the national energy sector. The research analyzes the sources of funding of the institutes' operations, their profitability and the financial effectiveness of their scientific and research staff. The results of the research indicate the adaptability of the surveyed institutes to the new rules of financing and the possibility of their wider than previously opening to business relations, as well as at least partial independence from budget financing. This is a valuable observation from the perspective of shaping innovation policy and the principles of operation of the national innovation system in developing economies.
\end{abstract}

Keywords: research institutes; innovation policy; national innovation system; funding of research institutes; effectiveness of research institutes

\section{Introduction}

Innovations are the driving force of the economy. Socio-economic and civilization development, which determines the quality of life of the population and the attractiveness of the region and the country, depends on the scale of their implementation and the level of advancement [1-3]. Thus, innovations are a national treasure which are sought not only by enterprises, but also by state and local authorities.

This leads to the formation of a network of dense economy-wide links. Their arrangement is consistent with successive helices, according to which-in the process of creating innovations-authorities, business, science, local community and environmental organizations participate [4-6]. Such cooperation contributes to the multiplication of innovation benefits due to the occurrence of economies of scale and synergies [7-9]. It is also a source of open innovation emerging with multiple stakeholders and shared by multiple users [10].

The sharing of knowledge and technology contributes to the diffusion of innovations and the release of their potential, which can inspire a wide range of potential creators of original and unique technological and/or application solutions.

Diffusion and absorption of knowledge and technologies accompanying such commonality can be an important element improving the competitiveness of economies in terms of individual and national innovation [11,12]. For these reasons, it is in the interest of the aforementioned state and local governments to support knowledge and technology transfer between science and business in order to add density to innovation networks and make resource and information flows more intense. As a rule, tasks in this area are 
undertaken within the national innovation system in accordance with the adopted national innovation strategy [13]. Typically, they are implemented by universities, scientific and research institutes and also at the local level by business accelerators and incubators and technology parks [14]. Some of these institutions are entrusted with the role of knowledge and technology creators. Some of them are responsible for effective knowledge and technology transfer [15]. They also include entities that organizationally, formally and financially support the system of national innovation.

However, the opening and commonality of innovation are accompanied by a number of problems. This is because, while closed innovations created and used at the level of individual entities are implemented commercially as part of private resources, open innovations are associated with the necessity of choosing sources of financing and rules of sharing [16,17]. The above-mentioned state and local government institutions most often use public funds and the effects of their activities are of the nature of social or public goods, which may raise controversies and doubts related to the legitimacy of such financing and its ultimate effectiveness and efficiency [18-20]. In response to such accusations, there are attempts to partially commercialize the activities of these institutions [21], aiming at tightening business relations and making the cooperation for the development of innovation, including support for open innovation, more effective.

Poland, as the EU's developing economy, has been in the group of the so-called moderate innovators and its position in innovation rankings is not satisfactory. In 2018, it was ranked 25th in the European Innovation Scoreboard report out of 28 EU countries. Compared to 2016, its position worsened by as many as three places. Behind it were only: Croatia, Bulgaria and Romania [22-33]. In view of the above circumstances, research on the effectiveness of pro-innovative solutions should be both considered justified from a practical and theoretical point of view.

One of such solutions, present in the national innovation system for years, is the activity of research institutes related to various fields of science and supporting the activities of various sectors of the economy. Their key task is to mediate the transfer and diffusion of knowledge and technology between science and business. Therefore, these institutesat least in principle-are to support innovation, including the open one and constitute an important element of the national innovation system. Unfortunately, the analyses and research conducted so far indicate a partial ineffectiveness and ineffectiveness of the institutes' activities, which raises the question of the legitimacy of their existence and financing from public funds [24,25].

In view of the importance of economic and financial issues related to the operation of innovation networks and non-commercial institutions forming them, this article analyses the sources of funding and the effectiveness of the functioning of selected groups of research institutes in Poland in the context of changes in the rules of their operation and the commercialization of the results of R\&D work (which is their primary statutory task). Research on the economic and financial conditions for innovation in the context of national innovation networks is rare; therefore, the analyses carried out in this article fill the existing cognitive gap in this area.

They are also a source of valuable information and recommendations for improving the functioning of institutions responsible for knowledge and technology transfer created at the state and/or local government level.

The further structure of considerations was subordinated to the main research intention. The structure of the paper begins with literature studies on open and closed innovation and the national innovation system.

Next, the discussion is narrowed down to the definition of the role of institutional participants in the system of national innovation established by the state/local authorities, as well as the principles of their financing and the evaluation of their effectiveness and efficiency. This context is a background to the analysis of the financial conditions for the functioning of research institutes in Poland as entities established to strengthen innovation and support knowledge and technology transfer between science and business. In research, 
financial statements of institutes and indicators of economic and financial analysis are used. The analysis also includes references to surveys conducted in research institutes in 2018 in terms of self-assessment of the level of their innovativeness and scientific and research facilities used in the process of creation and commercialization of R\&D work results. The whole discussion closes with a discussion referring to the previous research and conclusions containing a synthesis of the results and recommendations to improve the activity of entities supporting the national innovation system created at the national, local or regional level.

The results of the conducted research contribute to the development of knowledge about the principles of operation and effectiveness of national innovation systems. They document the practical effects of government actions to strengthen innovation, including open innovation. Their originality mainly results from the financial approach to the presented issues, which is rarely encountered in the literature on the subject. Another advantage of the research is the dynamic nature of the developed analyses, which allows us to observe the effectiveness and efficiency of research institutes over time, taking into account the results of changes and modifications in their operating aimed at strengthening and developing innovation in emerging economies. The empirical nature of the research allows for the formulation of useful practical recommendations from a micro and macro perspective, i.e., for managers of research institutes and for local, regional and national governments regarding the national innovation system.

In terms of geography, the research results can primarily be used in post-communist economies and emerging economies that create or modify a network of economic connections conducive to the development of innovation, including open innovation. They provide knowledge about the principles of financing intermediary institutions in the transfer of knowledge and technology and the relationship between these principles and the innovative effectiveness of these entities. This knowledge allows us to optimise the effects of innovative activities and stimulate the system of national innovations in the desired direction. In a broader context, it also enables the economic development of the mentioned economies and its balance in relation to more developed countries.

In institutional terms, the research results can be used wherever financial entities from public sources are established in the national innovation system. Then-due to the aforementioned inefficiencies of the public sector-it is necessary to monitor the results of the activities of these entities and prevent the waste of public funds.

\section{Literature Studies}

\subsection{Open Innovation as an Evolutionary Outcome of Knowledge and Technology Commonality}

Innovation is a response to the growing expectations and needs of today's consumers who desire new or significantly improved products, services, production, organizational and marketing standards. Failure to keep up with or meet these expectations is associated with a decline in competitiveness, reduced efficiency and, ultimately, loss of survivability and bankruptcy. For these reasons, every organization strives to be innovative. The source of its innovation is the ability to acquire, collect, process and use knowledge and technology in innovation processes [26,27].

Initially, knowledge and technology related to innovation were endogenous and were developed through the use of an organization's own resources with minimal participation of external factors. The innovations such created-currently referred to as closed innovations - were trade secrets protected from the competitors by the invention law. Their undoubted advantage was and is the possibility of exclusive use and, thus, the opportunity for rapid and effective market expansion in the case of the development of an innovation well received by users [28]. However, this advantage in practice means the necessity of having one's own qualified staff of specialists and incurring high expenditures on R\&D activities [29]. These circumstances limit innovation at the organization level and in the regional and national context [30]. 
The shortcomings of closed innovation are mitigated by the commonality of the process of their creation, which in practice is realized through the widespread transfer and diffusion of knowledge available to many stakeholders [31]. Thus, it is possible to effectively reduce the costs associated with the permanent employment of experts through their temporary use or cooperation with specialized scientific and research entities. Reduced costs provide benefits from the discoveries and inventions of other organizations, increasing the scope and range of their use. Resources-including financial resourcesrequired for innovation through sharing and co-use are reduced as well [32].

This approach-typical of open innovation-allows us to move away from the philosophy of market success at all costs to maximizing the quality and utility of innovation solutions for society as a whole. In open innovation, the issue of intellectual property is less important, what matters is the sharing of knowledge and technology to support the development of a unique business model. Consequently, the benefits of open innovation allow to better realize the goals of sustainable development [33-36], the concept of social responsibility and the fivefold economic helix [37-39], which is considered a condition for survival and good quality of life of future generations [40]. Thus, it can be concluded that from the point of view of socio-economic development, with its scale and intensity being primary factors, open innovation is more useful and effective than closed innovation. This is particularly important for developing economies, as emphasized by Elmustapha and Hoppe (2020) [41] in their study, proving that the use of business models that involve more the public and the ultimate customers favors the development of startups and the transfer and diffusion of new technologies.

However, it should be added that the final choice of the type of innovation implemented depends on the organization and its individual benefit-cost calculus conducted for the use of a specific solution [42]. For example, for start ups or SMEs, due to the limited resources they have, open innovation is a better development solution. Large companies or corporations with their own scientific and research facilities may tend to use closed innovations more often, although dissemination of their inventions and their mass evaluation (on the Internet) also significantly affect the development of open innovation.

\subsection{Open Innovations: System and Technological Complexity}

Open innovations [43,44]—due to their availability and being free of charge-require a systemic approach, without which their dissemination would not be possible; therefore, the literature on the subject emphasises their multi-level nature [45,46], referring to:

- the micro level, i.e., individual entities mainly using internal sources of innovation,

- the meso level, i.e., partnerships between enterprises and institutions supporting the development of innovation, which is conducive to the opening of innovation,

- the macro level, i.e., local, regional and national institutions supporting innovation based on external sources.

The need for a systemic approach to open innovations makes them more demanding than closed innovations. In addition to the appropriate level of entrepreneurship and resource base (at an individual level), a necessary condition for their creation is the existence and development of a network of cooperation between individual economic entities along the lines of the already mentioned helices: business, science, state, society and ecological environments $[47,48]$. The more real relationships are established in this network, the wider and faster the flow and diffusion of knowledge and technology, which is conducive to open innovation $[49,50]$.

However, it is worth noting that the following circumstances are needed to create the above system:

- the existence and development of individual and institutional entrepreneurship;

- an appropriate level of knowledge and technology that can be the subject of transfer and diffusion to stimulate innovation;

- a network of connections between economic entities based on mutual trust; 
- legislative and organisational support from the state and local self-government in initiating cooperation and creating conditions for the development of open innovation.

Therefore, creating open innovations takes place in conditions of high system complexity. The development of open innovations will depend on the effectiveness of the system characterised above in more detail in the next subchapter.

It should also be added that the system of creating open innovations must be supplied with an appropriate stream of knowledge enabling the emergence of new technological solutions. Currently, this knowledge is complex, often interdisciplinary and its acquisition and use are associated with an appropriate level of competence and education of both inventors and the communities in which they will be disseminated. In the case of developing and post-communist economies, isolated for many years in terms of civilisation and economy from Western countries, this condition is not easy to fulfil. This is all the more so as these economies have mainly been developing traditional industries for many years, which are currently in decline. Meanwhile, modern innovation is largely related to the IT and ICT sectors. Many open innovations also appear within ecosystems and concern clean production and service technologies [51-55]. Developing economies also do not have much of their own experience in this area and environmental organisations rarely play an important role in social and economic life. In the above circumstances, both technological and ecological education play extremely important roles in the innovation system, enabling the increase of social awareness of the role of innovation and ecology. Without it, radical technological reorientation will not be possible.

At the end of the considerations on the complexity of the open innovation system, it is also worth referring to the reality and depth of the created connections between individual entities of successive economic helices, which should be full and active. Meanwhile, according to research conducted in Poland, the main type of cooperation between entities is concluding formalised agreements with partners from the common economic sector. This, in turn, is not conducive to the complementarity of knowledge and experience and may hinder the creation of open innovations [56,57].

\subsection{Innovation Policy and the National Innovation System as an Expression of State Involvement} in the Development of Open Innovation

In the institutional context, closed and open innovation naturally fit into the type and evolution of the adopted and implemented national innovation policy. This policy is divided into traditional (narrowed) and systemic [58-60].

Traditional (narrow) innovation policy is based on the concept of laissez-faire, according to which the market is governed by the law of supply and demand. Prices and market relations are formed on its basis. State intervention in the economy is limited to a minimum, which in practice means that its activity is limited only to countercyclical actions. As a result, innovation activity is an individual matter of a given organization and the effects of innovation are evaluated by the market and its participants. Such an approach favors the creation of closed innovations, including mainly those of a technological nature. In the traditional innovation policy, the role of the state is reduced to subsidizing a narrow group of scientific and research units whose activities are oriented towards key sectors of economic development. The network of support for creativity and innovation is not structured and extensive.

In the systemic innovation policy, the network of links between economic entities is very wide and dense, which by definition promotes the transfer and diffusion of knowledge and technologies necessary for the emergence of innovations [61-63]. In this case, the number and scope of institutions mediating this transfer definitely increases. Numerous industrial clusters and technological cooperation networks are formed. The state is involved in their formation and financing, which, as Gabriel and Kirkwood (2016) [64] point out, is important for innovation and the business models used in it. Closer and denser ties foster cognitive and social proximity, which in turn has a very good positive impact on the growth of innovation, including open innovation [65-68]. 
The formal dimension of the tasks and role of the state is usually the national innovation system. By definition, it is a system of political, social, technological and institutional factors that supports the development, diffusion and use of innovations [69-72]. The main task of the national innovation system is to create effective and efficient links among the entities that generate knowledge and technology and the entities that can consume them to produce new products and provide new services [73,74]. This system includes:

- Knowledge and technology creators as donors of discoveries and inventions (universities; scientific and research institutes) [75-77];

- Knowledge and technology users, i.e., enterprises and economic and social institutions;

- Innovation promoters responsible for the development and popularization of innovation policy (accelerators and incubators; technology centers and parks; information centers) [78-80].

The effectiveness and efficiency of the innovation system depends on many internal and external conditions [81]. The key one is access to knowledge and technologies and their level of advancement $[82,83]$. The economic situation, including the availability of financial resources and the competitiveness of the economy, is also not without significance. Among the social determinants, the level and system of education is important, including the extent of its internationalization strongly affecting the transfer and diffusion of knowledge $[84,85]$. Finally, legal and political conditions are also important, especially the rules of intellectual property protection and the involvement of state and local authorities in the development of innovation [86,87].

\subsection{The Role of Knowledge and Technology Creators in the Innovation Policy and System}

Knowledge and technology are at the core of every innovation; therefore, innovation creators, most often universities and scientific/research institutions, are the first link of innovation formation [88]. The level of sophistication and scope of intellectual and technological resources that form the basis for the creation of innovations, both closed and open, depends on the effectiveness of their actions.

Nevertheless, in addition to the generation of knowledge and technology, their transfer, diffusion and absorption by users is needed to trigger innovation generation. These processes can be implemented directly under science-business contacts [89]. They can also be assisted by the aforementioned innovation promoters. Efficient and effective transfer of knowledge and technology to the level of their operationalization is one of the key conditions for commercialization and materialization of the results of R\&D conducted in universities and scientific institutes [90,91].

In Poland, the role of knowledge and technology creators in the national innovation system has been entrusted to universities and research institutes, which are the center of attention as part of the considerations and research conducted. Research institutes, unlike universities, do not offer education.

They are state-owned organizational units, separate under legal, organizational, economic and financial terms, which conduct scientific research and development work aimed at their implementation and application in practice. The basic tasks of a research institute include: (1) scientific research and development; (2) adapting the results of scientific research and development to the needs of practice; and (3) implementing the results of scientific R\&D. Furthermore, an institute can:

- $\quad$ disseminate results of scientific research and development works;

- $\quad$ perform research and analysis as well as develop opinions and expertise within the scope of the conducted R\&D;

- develop assessments regarding the status and development of individual fields of science and technology and sectors of the economy;

- $\quad$ perform standardization, certification and approval activities;

- run and develop databases related to the scope of Institute's activity; 
- research scientific, technical and economic information, inventiveness and protection of industrial and intellectual property, as well as supporting innovativeness of enterprises;

- produce instruments, devices, materials and other products in connection with the conducted scientific research and development works and conduct the validation of research and measurement methods and the calibration of apparatus;

- perform publishing activities related to scientific research and development works [92].

Institutes, due to their statutory tasks and directions of research and development work, are supervised by competent ministers.

The majority of research institutes are active in the area of science and engineering $(58 \%)$ and life sciences $(34 \%)$, while the remainder $(8 \%)$ operate in the area of humanities and social sciences. Their research and implementation are evaluated by the Committee for the Evaluation of Scientific Units at the ministerial level [93].

The institutes are financed under a hybrid scheme. They receive a statutory subsidy from the state budget and the remaining funds are obtained independently in cooperation with the socio-economic environment. Unfortunately, budget support very often leads to demotivation of institutes and limits their activity for cooperation with enterprises [94]. The 2014 report of the Supreme Audit Office showed a number of irregularities in the functioning of the audited research institutes among which we should point out the following:

- ineffective use of the scientific potential of the institutes' staff;

- concentrating activities on performing services unrelated to scientific research and development work;

- generating insignificant revenues from sales of research and goal-oriented projects and a limited scope of R\&D activity undermining the status of some units as research institutes.

The biggest problem for these institutions was and still is the insignificance of the implementation effects. Between 2010 and 2013, the twofold increase in patented inventions did not translate into a proportional increase in their use, as only $20 \%$ of them were implemented in practice. It is worth adding that in highly developed countries this percentage is more than $50 \%$. Another problem of Polish research institutes is a very low-around $5 \%$ - percentage of international patents, which indicates a very low level of international exposure and limits the transfer and diffusion of innovation. This is a very serious systemic problem, because studies to date very clearly show that the level of commercialization of the results of scientific and research work significantly affects the opportunities for development and transformation of the socio-technological system [95], which, for emerging economies, such as Poland, is particularly desirable and important. The development of knowledge and innovation is also fostered by international cooperation, which is emphasized in their studies by Boschma (2005) [96], Knoben and Oerlemans (2006) [97], Capello (2009) [98] and Möller and Halinen (1999) [99].

During audits, a decreasing value of revenues from commercialization of R\&D works was also found, which confirmed the substitution of external financing by public funds responsible for the lack of motivation for real innovation activities. This phenomenon occurs also in other economies, not only Polish [100]. Many international studies indicate problems with ensuring adequate efficiency and effectiveness of public funds spent in the sphere of science. A lot of attention and effort is also given in this context to defining and parameterizing the system of evaluation of public scientific units [101-103].

The above circumstances have resulted in statutory changes in the operations of Polish research institutes. These changes concerned two key areas:

1. organisation and operation of research institutes and were sanctioned in two subsequent amendments to the act directly referring to this group of entities (Act of 22 June 2016 amending the Act on research institutes, Journal of Laws 2017, item 202; Act of 16 December 2016 amending the Act on Research Institutes and the Act-Geological and Mining Law, Journal of Laws 2017, item 202); 
2. the evaluation of scientific research activity of research institutes as entities of the science sector in Poland (implementation of the new act regarding Law on Higher Education and Science, Journal of Laws 2018, item 1668 and the Regulation of the Minister of Science and Higher Education on the evaluation of the quality of scientific activity, Journal of Laws 2019, item 392).

The new rules for the organisation of research institutes introduced the following changes:

- making the selection of the institute's authorities dependent on the decision of the minister who supervises the functioning of the institute, which strengthened the rank of external ownership evaluation and allowed the institutes to become more closely integrated into the national innovation system;

- inclusion of external stakeholders in the scientific council of institutes ( $\mathrm{min} .50 \%$ ) in order to objectify the decisions made so far among only the employees of the institute and to open the institute to the needs and suggestions of the socio-economic environment;

- the election of the chairman of the scientific council from among external stakeholders, which was to make decisions made at the institute independent of internal factors and to reduce the hermetic nature of these departments.

The changes to the rules of assessing the quality of scientific activity concerned all participants of the national innovation system in Poland and were aimed at achieving the following goals:

- increasing the level of internationalisation of Polish science by rewarding publications in renowned foreign journals (TOP 1; TOP 10; Journal Citation Report);

- activation of all research workers employed in research and development departments by limiting the number of scientific achievements submitted for evaluation by one person (the need to bring at least 3 publications by each employee and not the collection of high-rated publications by random authors, e.g., $10-15 \%$ of employees in the department);

- intensification of cooperation of scientific research departments with the socio-economic environment to increase the innovativeness of the Polish economy, including the transfer of knowledge and technology as part of open innovations;

- making financing and, thus, the development and possibility of the existence of research institutes dependent on the obtained scientific category, which is the result of the evaluation of the achievements: publication, patent, research and cooperation.

These changes were and are aimed primarily at increasing activity in the commercialization of R\&D results and, thus, making the operation of institutes independent of public funds. In practice, this means making the funds received dependent mainly on:

- quality and the number of scientific publications in prestigious scientific journals (Journal Citation Report);

- the number of citations of scientific publications in the above-mentioned journals;

- the revenue obtained from external scientific and research projects and from commercialization of the results of R\&D;

- number of patents, protection rights for utility models, rights from registration of industrial designs.

In the context of the above-mentioned changes, this article addresses the issue of assessing the effectiveness of their implementation in several selected case studies of research institutes in Poland. The methodology of this evaluation and its results are presented further herein.

\section{Materials and Methods}

\subsection{Research Intent and Methodology}

As already quoted, the main objective of organizations responsible for the creation of knowledge and technology is to disseminate, including commercialization of R\&D 
results. Unfortunately, as can be seen from the above cited studies and considerations, this task is not always carried out effectively because it is hampered by, among other things, public financing and certain economic and technological deficiencies present in developing economies or those aspiring to be such economies. Therefore, this article focuses on the activities of Polish research institutes. Poland is an emerging and developing economy, interested in effective knowledge and technology transfer and innovation development. Moreover, the above-cited control of state authorities in research institutes showed ineffective activities concerning innovation and commercialization of R\&D results. This took place in 2014 and initiated a number of changes in the functioning of research institutes.

This article seeks to answer the question about the effects of the introduced changes from the following perspectives:

1. capital, referring to the structure of financing sources, including the issue of the share of equity and foreign capital;

2. financial independence, relating to the share and dynamics of public (subsidies) and private (commercialization) revenues in total revenues;

3. effectiveness, allowing for classic evaluation of profitability of sales, assets and capital of the studied units;

4. employment, informing about the effects of research institute activity per employee.

Monetary amounts were expressed in the analyses carried out using the Polish currency, which is the new Polish zloty (PLN). This currency unit is divided into 100 groszy100 Polish cents.

In the case of the first research perspective, structure indicators were used in relation to liabilities, including equity and short- and long-term liabilities. For the second research perspective, structure and dynamics indicators were used to assess changes in public grant and commercialization revenues. The third research perspective was evaluated in the context of classic profitability ratios: return on sale (ROS), return on equity (ROE) and return on assets (ROA) by dividing net profit by, respectively, sales revenue, equity and total assets. In the last of the perspectives, the author's evaluation mechanism was proposed, in which the conversion of the result from sales (reflecting the basic aspect of the institutes' activity) per employee was taken into account, according to the evaluation of the effectiveness of the possessed human resources, constituting the possibilities of knowledge and technology creation in the process of innovation support. From this perspective, reference was also made to efficiency in the context of generating inventions, treating them as a measurable effect of innovative activity.

The research period covered 2014-2019. This six-year period was considered sufficient to observe long-term changes in financing and the efficiency of research institutes. In the period defined, 2 years (2014-2015) reflected the operation of the institutes before the legal changes relating to their operating; 2016 was the year of introducing the changes and the period of 2017-2019 made it possible to observe the effects of the introduced changes. According to the author, the three-year period after the change gives grounds for inference in terms of adaptation processes or their lack thereof, because the lack of response to changes even in the medium term research perspective in the area of financing would contribute to the closing of the entity, which also took place in the analysed period in the case of several other institutes running on the system. The study used the financial reports of research institutes posted on the websites of the relevant ministries to which their activities are subject.

Furthermore, outside the above characterized analysis, the article refers to the results of a survey conducted in 2018 in research institutes in Poland [104-107] relating to the self-assessment of innovation-related organizational factors, such as

- working in a highly prestigious institution;

- the possibility to work in highly innovative conditions (modern equipment, access to new technology); 
- $\quad$ initiating contacts with the external environment by the institute's authorities (contacts with enterprises; cooperation with scientific and academic units; internationalization of activities).

Research results obtained in this area are used to explain, at least partially, the mechanisms operating in these units. The research in question involved 215 employees from 24 research institutes.

\subsection{Selection and Characteristics of Case Studies}

There were 104 research institutes in Poland as of March 2021. This article uses a multiple case study to evaluate the sources of funding and their effects, a method often used in economic and social sciences. Its main advantage is the ability to focus on the essence of the activity and deeper causal analysis, which, in the process of evaluating the effects of legislative and organizational changes, brings better diagnostic and recommendation results.

Nevertheless, the case study does not allow broad generalization of research results due to the small number of analyzed entities [108,109].

As already mentioned, research institutes in Poland represent various scientific disciplines and industries, which requires concretization of the research sample. Thus, further analysis will focus on entities operating in two currently important economic areas for Poland, which are energy and environmental protection. Poland-due to the dominant use of hard coal in the power industry-is currently facing a huge technological challenge, which is energy transformation. The main goal of this transformation is shifting away from coal to less carbon-intensive fuels and renewable energy sources [110-113]. This shift requires effective actions both in the field of energy and environmental protection, including reclamation of post-mining areas.

Due to long mining traditions, several large institutes are associated with mining and mining-related industries. The analysis includes 3 institutes, which have attempted to re-brand themselves and find new directions of development in the last few years. In addition, included in the sample are 2 large research institutes currently and formerly involved in ecology, including the ecology of industrialized areas [37,114-116].

Such a selection of the research sample allowed to additionally answer the question: did the surveyed entities manage to take advantage of the opportunities and mitigate the risks associated with the energy transformation of the Polish economy? Mining institutes have been forced to reorientate the market and look for new markets, which, in the case of scientific research activities, is a very difficult task due to the long and not always effective process of developing innovative products and services. In turn, environmental institutes have gained importance thanks to the increased environmental awareness of the EU's policy of decarbonisation and environmental protection. They were also allowed to join the mine decommissioning processes, including minimising the negative impact of this process on the natural environment and rehabilitating post-mining areas.

The general characteristics of the entities selected for the study are presented in Table 1. A detailed description of the directions of the institutes' activities is presented in Appendix A in this article.

Table 1 shows that the largest research institutes in terms of the number of employees are those that have been long related to the power industry, especially coal mining. In the last few years, due to the systematic liquidation of mines in Poland, these institutes have been forced to reorient strategically. In the case of two of them, the newly chosen direction turned out to be environmental protection, including renewable energy sources. The third one, related to the mining machinery industry, evolved towards production and transport solutions. In the case of environmental institutes, the sample includes a leading institute dealing with ecological issues in Poland and a smaller unit, whose activities are indirectly related to mining regions. 
Table 1. The characteristics of the entities selected for the study.

\begin{tabular}{ccc}
\hline Business Area & Business Scope & Number of Employees \\
\hline $\begin{array}{c}\text { Ecology } \\
\text { (ECO 1) }\end{array}$ & $\begin{array}{c}\text { Development of the national environmental } \\
\text { strategy and policy }\end{array}$ & 68 \\
\hline $\begin{array}{c}\text { Ecology } \\
\text { (especially in industrialized and urbanized areas) } \\
\text { (ECO 2) }\end{array}$ & $\begin{array}{c}\text { Environmental protection in industrialized and } \\
\text { urbanized areas including closed loop economy } \\
\text { and climate change adaptation and mitigation. }\end{array}$ & 34 \\
\hline $\begin{array}{c}\text { Energy sector } \\
\text { (especially mining industry) } \\
\text { (EN 1) }\end{array}$ & $\begin{array}{c}\text { Mining and geoengineering, industrial safety, } \\
\text { environmental engineering. }\end{array}$ & 279 \\
\hline $\begin{array}{c}\text { Power engineering and environmental protection } \\
\text { (in chemical processing of coal) } \\
\text { (EN 2) }\end{array}$ & $\begin{array}{c}\text { Utilization of fossil, renewable and alternative } \\
\text { fuels, including thermochemical processing in } \\
\text { gasification, pyrolysis and combustion. }\end{array}$ \\
\hline Mechanization of the mining industry \\
(EN 3) & $\begin{array}{c}\text { Mechanization of mining and processing in the } \\
\text { mining industry and mechanization of } \\
\text { production and transportation. }\end{array}$ & 105 \\
\hline
\end{tabular}

Source: own compilation based on data from the Rad-on system.

\section{Results}

\subsection{Assessment of Financial Stability in the Context of Financing Sources}

The first stage of the research included evaluation of the capital structure of research institutes divided into equity and long-term and short-term liabilities.

The results of this stage are presented in Table 2.

Table 2. Capital structure of the surveyed research institutes in 2014-2019.

\begin{tabular}{|c|c|c|c|c|c|c|}
\hline \multirow{3}{*}{ Institute } & \multicolumn{6}{|c|}{ Years } \\
\hline & 2014 & 2015 & 2016 & 2017 & 2018 & 2019 \\
\hline & \multicolumn{6}{|c|}{ Equity Share [\%] } \\
\hline ECO 1 & $81.45 \%$ & $84.88 \%$ & $77.62 \%$ & $71.38 \%$ & $70.52 \%$ & $60.11 \%$ \\
\hline ECO 2 & $23.68 \%$ & $17.96 \%$ & $22.72 \%$ & $24.22 \%$ & $23.64 \%$ & $29.88 \%$ \\
\hline EN 1 & $44.77 \%$ & $48.62 \%$ & $51.76 \%$ & $50.99 \%$ & $50.33 \%$ & $53.30 \%$ \\
\hline EN 2 & $19.05 \%$ & $20.94 \%$ & $24.13 \%$ & $26.47 \%$ & $28.06 \%$ & $26.10 \%$ \\
\hline EN 3 & $59.70 \%$ & $61.33 \%$ & $61.21 \%$ & $63.82 \%$ & $68.50 \%$ & $70.38 \%$ \\
\hline \multirow{3}{*}{ Institute } & \multicolumn{6}{|c|}{ Years } \\
\hline & 2014 & 2015 & 2016 & 2017 & 2018 & 2019 \\
\hline & \multicolumn{6}{|c|}{ Long-Term Liabilities [\%] } \\
\hline ECO 1 & $0.00 \%$ & $0.00 \%$ & $0.00 \%$ & $1.34 \%$ & $0.16 \%$ & $0.53 \%$ \\
\hline ECO 2 & $0.00 \%$ & $0.00 \%$ & $0.00 \%$ & $0.00 \%$ & $0.00 \%$ & $0.01 \%$ \\
\hline EN 1 & $0.27 \%$ & $0.31 \%$ & $0.58 \%$ & $0.36 \%$ & $0.31 \%$ & $0.36 \%$ \\
\hline EN 2 & $0.00 \%$ & $0.00 \%$ & $15.09 \%$ & $0.00 \%$ & $0.00 \%$ & $0.00 \%$ \\
\hline EN 3 & $0.00 \%$ & $0.00 \%$ & $20.67 \%$ & $0.00 \%$ & $0.00 \%$ & $0.00 \%$ \\
\hline \multirow{3}{*}{ Institute } & \multicolumn{6}{|c|}{ Years } \\
\hline & 2014 & 2015 & 2016 & 2017 & 2018 & 2019 \\
\hline & \multicolumn{6}{|c|}{ Short-Term Liabilities [\%] } \\
\hline ECO 1 & $12.64 \%$ & $7.63 \%$ & $11.48 \%$ & $15.73 \%$ & $15.65 \%$ & $12.31 \%$ \\
\hline ECO 2 & $9.47 \%$ & $8.62 \%$ & $12.30 \%$ & $21.85 \%$ & $15.65 \%$ & $15.18 \%$ \\
\hline EN 1 & $8.90 \%$ & $8.31 \%$ & $7.93 \%$ & $8.83 \%$ & $10.32 \%$ & $9.68 \%$ \\
\hline EN 2 & $12.33 \%$ & $14.10 \%$ & $15.09 \%$ & $19.03 \%$ & $18.60 \%$ & $19.83 \%$ \\
\hline EN 3 & $21.35 \%$ & $22.03 \%$ & $20.67 \%$ & $19.30 \%$ & $18.27 \%$ & $17.00 \%$ \\
\hline
\end{tabular}

Source: own elaboration based on financial statements. 
The state is the owner and founder of research institutes in Poland. Equity contributed by the founder at the time the institute was established and owned by the state. It is systematically supplemented by the profit generated in the course of business.

The dominant share of equity, guaranteeing a stable funding basis, was present in the leading environmental institute (ECO 1) and one energy institute (EN 3), indirectly related to coal mining. Both of these institutes also showed a low level of short-term liabilities with little variation over time and very low or no long-term debt, which put these entities in a very secure financial position throughout the analyzed period.

The largest energy institute (EN 1) was also financially stable, with its share of equity steadily increasing from $44 \%$ to over 53\% between 2014 and 2019. This institute was also funded to a very small extent by short-term liabilities (about 10\%) and long-term liabilities (about $0.5 \%$ ). This capital structure meant that the funding risk was low and stable over time.

Increased funding risk was observed in two of the five institutes studied (ECO 2 and EN 2). In both of these entities, the share of equity did not exceed $30 \%$ throughout the analyzed period, which means that the total debt was above $70 \%$ and, thus, exceeded the acceptable norm (maximum 67\%). Such a high level of debt was attributable to short-term liabilities and, in the dominant part, long-term accruals.

\subsection{Assessment of Financial Stability against Revenue Structure}

Current sources of financing for research institutes in Poland, defined in the profit and loss account in the form of revenues, primarily include, in accordance with the applicable legal regulations, two components:

- $\quad$ subsidy for research activities financed from the state budget-budgetary source;

- revenues from the sale of research services and products obtained as part of commercialisation of the results of R\&D works-extra-budgetary sources.

The above-mentioned sources are supplemented by scientific research projects that can be financed from domestic and foreign research programmes established by state or private institutions.

With the above in mind, in the second stage of the research, the independence of research institutes was assessed against their revenue structure. It was assumed, in this respect, that the higher the share of revenue from commercialization of R\&D work in total revenue, the greater the degree of independence from public funding in the form of subsidies granted by the ministry for research institutes. The results of this stage are presented in Figure 1.

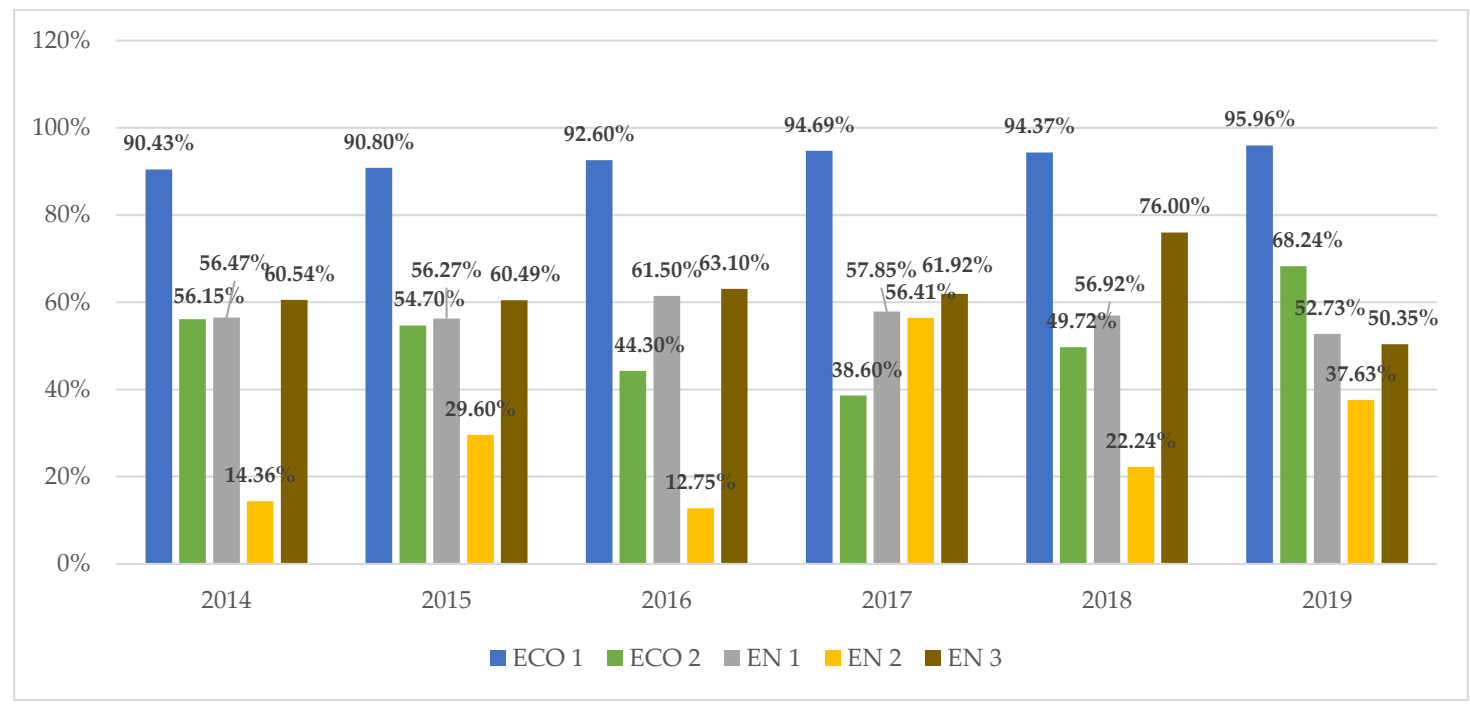

Figure 1. Share of commercialization revenue in total revenue of surveyed research institutes from 2014 to 2019. Source: own compilation based on the financial statements. 
Among the surveyed institutes, we can distinguish three groups. The first—clearly different from the others-includes the leading national institute dealing with environmental protection (ECO 1). In this institute, the share of commercial revenues exceeded $90 \%$ throughout the analyzed period and also steadily increased over time. This demonstrates the financial independence of this unit and the ability to obtain funds from cooperation with the socio-economic environment. It is certainly fostered by increased market demand for research and services in the environmental protection related to the EU environmental policy and the growing environmental awareness of the EU population, including Poland [117-119]. Nevertheless, it should be added that a significant part of the Institute's non-grant revenues came from the proceeds of the sale of goods and services to the Ministry of the Environment, the National Fund for Environmental Protection and Water Management and the National Center for Balancing and Emission Management administering the EU Emission Trading Scheme in Poland. Therefore, it may be assumed that a significant part of the revenues generated by this institute was also of a quasi-budgetary nature, as it resulted from the performance of tasks commissioned by the state. However, it was not a direct support shaped as general purpose subsidies.

The second group of research institutes in terms of independence of financing includes three units: ECO 2, EN 1 and EN 3. In these units, the share of non-subsidized revenue in the analyzed period ranged from $44 \%$ to over $68 \%$, which indicates partial independence of operations from budgetary funds.

In addition, the value of this share fluctuated in time without a clear unidirectional development trend, which indicates the instability of this type of revenue and increases the risk associated with its planning and acquisition.

The third group, in terms of independence of financing, included the energy and mining institutes, in which the share of commercial revenues was the lowest and very variable over time (EN 2). Its value oscillated between $12 \%$ and over $37 \%$. This variability resulted from both high variability of the value of budget subsidies and irregularity of revenues from commercialization of R\&D results.

The main sources of extra-budgetary income in the analyzed period in all institutes were:

- research commissioned by social and economic environment entities;

- revenues from participation in national research projects;

- revenues from participation in international research programs;

- revenues from works commissioned by ministries and other government and/or local government institutions.

In addition to the analysis of the structure of sales revenues, the dynamics of subsidies, commercialization revenues and operating costs of the studied units were also examined in the described stage. The results are presented in Table 3.

According to the data in Table 3, the level of subsidy was highly variable in all institutes over time. Nevertheless, since the period of the last ministerial evaluation of the effects of scientific activity undertaken in 2016, higher subsidy was systematically received by institutes related to energy (EN 1; EN 2; EN 3). This means that the change in the rules of financing of scientific research units in Poland motivated them more strongly to publish and undertake project activities compared to environmental institutes (ECO 1 and ECO 2). Certainly, the systematic liquidation of hard coal mining forcing the strategic reorientation of these units and strengthening the will to survive, including maintaining or only slightly reducing jobs, also contributed to the increase of this motivation.

In the case of revenues from other research activity, including the commercialization of R\&D, no clear and stable trend of change was observed. Periodically, the value of these revenues was improved when compared to the previous year. In this context, the best results were achieved by ecological institutes. In ECO 2, the increase in the described revenues concerned three out of six analyzed periods and, in ECO 1, two periods. EN 1 and EN 2 recorded two such cases and EN 3 only one. However, it should be emphasized that for four out of five studied units, the record year in terms of growth of extra-budgetary revenues turned out to be 2017, which strongly exposes the reaction to the change of 
financing rules falling, as mentioned, in 2016. In the difficult year in which the COVID19 pandemic began, i.e., 2019, a mildly dynamic growth of other revenues was already recorded only by ecological institutes, less dependent on industrial enterprises (and more on government orders) and, therefore, more resistant to economic fluctuations. The unrest in the raw materials market caused by the growing pandemic in China quickly spread and translated into increased uncertainty in the operations of Polish mining enterprises already in the fourth quarter of 2019. In turn, this resulted in limiting the possibility of commercialising the results of $R \& D$ works in cooperating energy institutes and dependence on the financial capabilities of these enterprises.

Table 3. Revenue and cost dynamics of the surveyed research institutes from 2014 to 2019 (year-on-year).

\begin{tabular}{|c|c|c|c|c|c|c|}
\hline \multirow{3}{*}{ Institute } & \multicolumn{6}{|c|}{ Years } \\
\hline & 2014 & 2015 & 2016 & 2017 & 2018 & 2019 \\
\hline & \multicolumn{6}{|c|}{ Subsidy Dynamics [\%] } \\
\hline ECO 1 & $100 \%$ & $-7.2 \%$ & $-15.0 \%$ & $14.1 \%$ & $-3.7 \%$ & $-5.3 \%$ \\
\hline ECO 2 & $100 \%$ & $1.1 \%$ & $17.4 \%$ & $20.5 \%$ & $-25.7 \%$ & $-40.5 \%$ \\
\hline EN 1 & $100 \%$ & $-9.7 \%$ & $-19.0 \%$ & $15.6 \%$ & $13.7 \%$ & $11.6 \%$ \\
\hline EN 2 & $100 \%$ & $-37.6 \%$ & $-11.5 \%$ & $-41.8 \%$ & $41.8 \%$ & $14.0 \%$ \\
\hline EN 3 & $100 \%$ & $-8.3 \%$ & $-13.8 \%$ & $17.0 \%$ & $15.9 \%$ & $2.9 \%$ \\
\hline \multirow{3}{*}{ Institute } & \multicolumn{6}{|c|}{ Years } \\
\hline & 2014 & 2015 & 2016 & 2017 & 2018 & 2019 \\
\hline & \multicolumn{6}{|c|}{ Other Revenue Dynamics [\%] } \\
\hline ECO 1 & $100 \%$ & $-3.8 \%$ & $8.6 \%$ & $62.7 \%$ & $-9.5 \%$ & $34.2 \%$ \\
\hline ECO 2 & $100 \%$ & $76.3 \%$ & $79.1 \%$ & $149.3 \%$ & $-8.8 \%$ & $96.3 \%$ \\
\hline EN 1 & $100 \%$ & $-10.4 \%$ & $0.5 \%$ & $-0.7 \%$ & $9.5 \%$ & $-5.8 \%$ \\
\hline EN 2 & $100 \%$ & $56.4 \%$ & $-69.2 \%$ & $415.8 \%$ & $-24.0 \%$ & $-0.8 \%$ \\
\hline EN 3 & $100 \%$ & $-8.5 \%$ & $-3.7 \%$ & $11.3 \%$ & $-18.4 \%$ & $-8.9 \%$ \\
\hline \multirow{3}{*}{ Institute } & \multicolumn{6}{|c|}{ Years } \\
\hline & 2014 & 2015 & 2016 & 2017 & 2018 & 2019 \\
\hline & \multicolumn{6}{|c|}{ Operating Cost Dynamics [\%] } \\
\hline ECO 1 & $100 \%$ & $11.4 \%$ & $3.9 \%$ & $62.6 \%$ & $-8.7 \%$ & $26.2 \%$ \\
\hline ECO 2 & $100 \%$ & $-14.2 \%$ & $-3.1 \%$ & $7.6 \%$ & $-8.8 \%$ & $-3.9 \%$ \\
\hline EN 1 & $100 \%$ & $-7.8 \%$ & $-4.6 \%$ & $6.3 \%$ & $6.4 \%$ & $-1.4 \%$ \\
\hline EN 2 & $100 \%$ & $-18.5 \%$ & $-22.2 \%$ & $6.6 \%$ & $-13.2 \%$ & $-2.3 \%$ \\
\hline EN 3 & $100 \%$ & $-5.7 \%$ & $-8.4 \%$ & $6.8 \%$ & $-3.8 \%$ & $-2.2 \%$ \\
\hline
\end{tabular}

Source: own elaboration based on financial statements.

The institutes associated with traditional energy also made numerous attempts to reduce their core business costs. Due to the lower value of subsidies and the decrease in other revenues, the greatest cost reduction was recorded by EN 2, where cost reductions also occurred in the last two years of the analysis. A similar trend, but on a smaller scale, occurred at EN 3 and, outside of 2018, also at EN 1. The loss of the market and reorientation pressures thus forced both efforts for additional revenue and efforts to reduce the cost load. Costs were also reduced intensively at ECO 2, the smaller organic unit. The leader of the list, ECO 1, due to its good revenue situation, reduced its operating costs compared to the previous year only in 2017. The observed circumstances testify to the active adaptation of the surveyed institutes to market conditions, which indicates high adaptability and flexibility in their operations.

The above statement is also confirmed by the fact that all analyzed units achieved a positive net financial result during the entire research period, further described in the context of profitability in the next subsection. 


\subsection{Financial, Employment and Patent Profitability Assessment}

The final stage of the study addressed the financial and employment profitability of the surveyed research institutes. The results for the former are presented in Figures 2-4. According to Figure 2, the profitability of assets of the surveyed research institutes ranged from $0.33 \%$ to $4.56 \%$, which means that 1 PLN of assets brought about 1-5 PL cent of net profit.

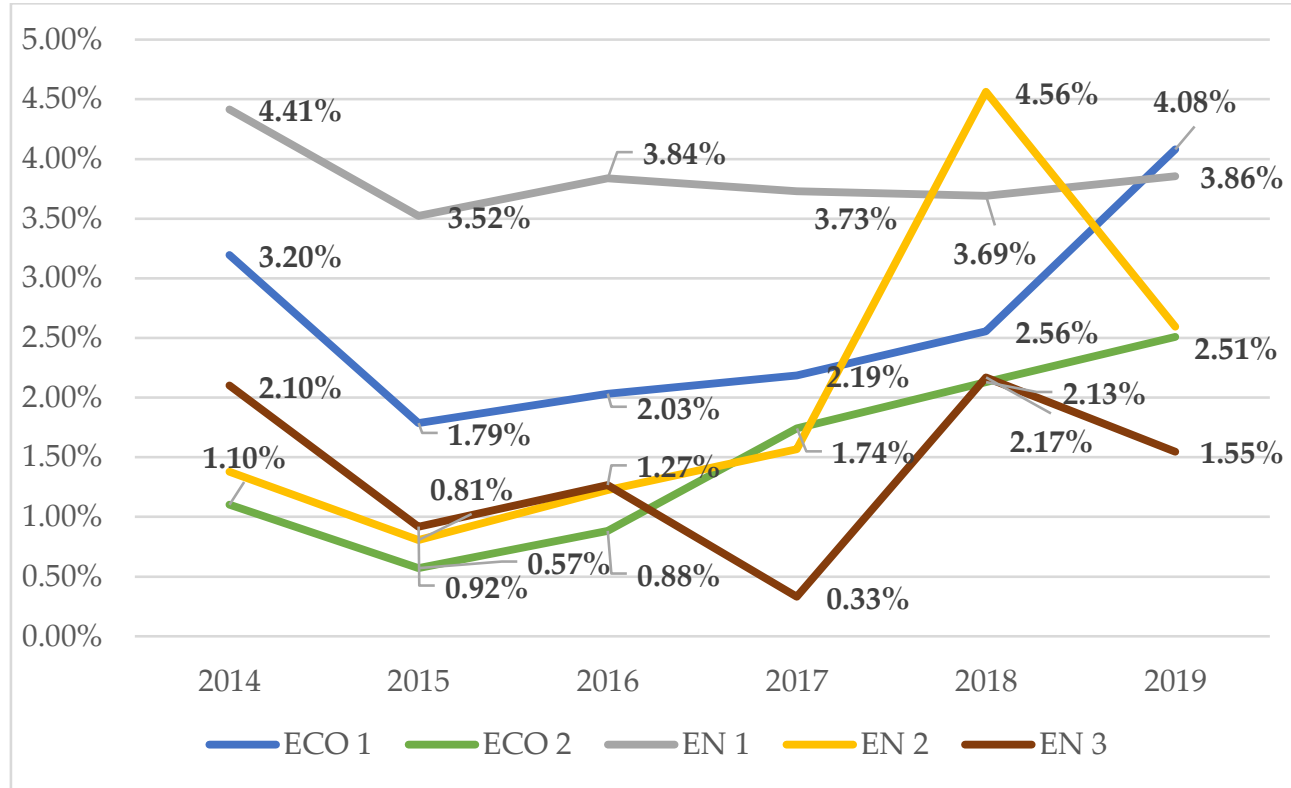

Figure 2. ROA at the surveyed research institutes in 2014-2019. Source: own compilation based on the financial statements.

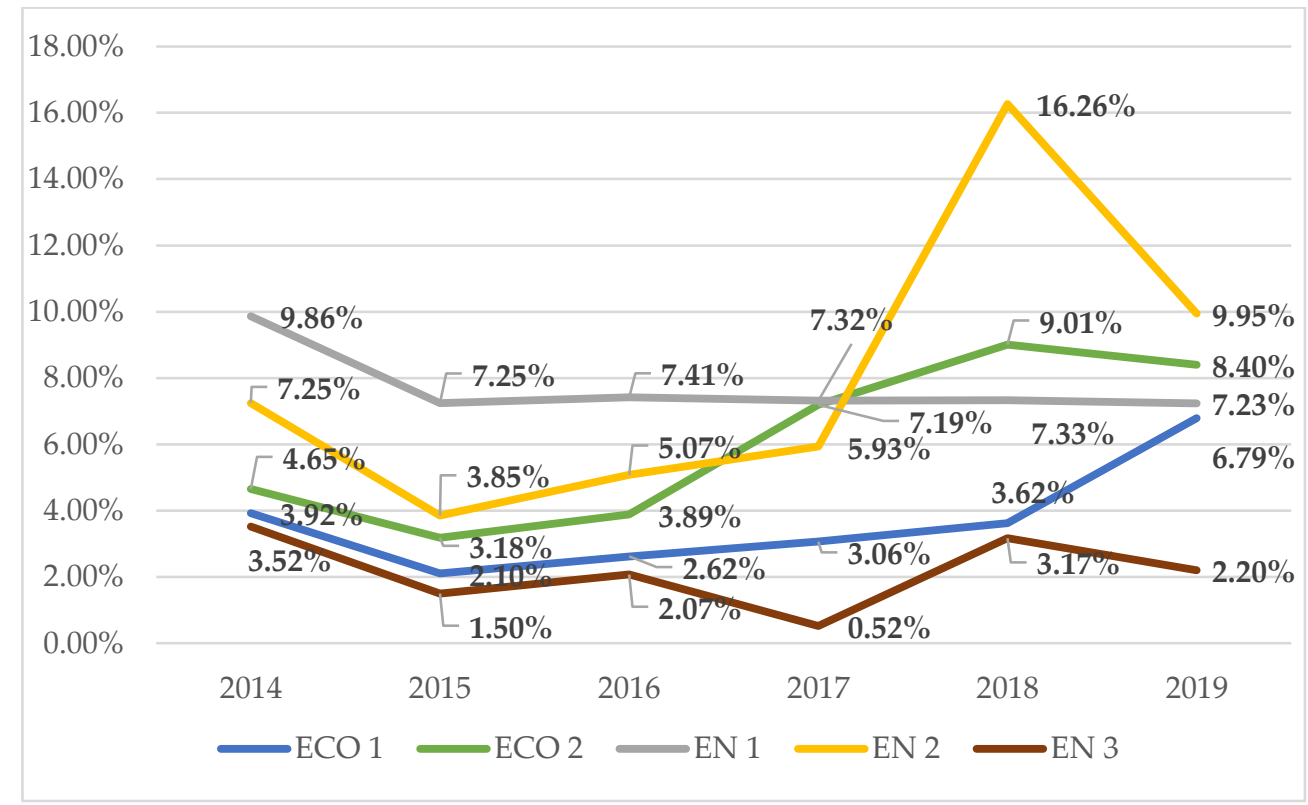

Figure 3. ROE at the surveyed research institutes in 2014-2019. Source: own compilation based on the financial statements. 


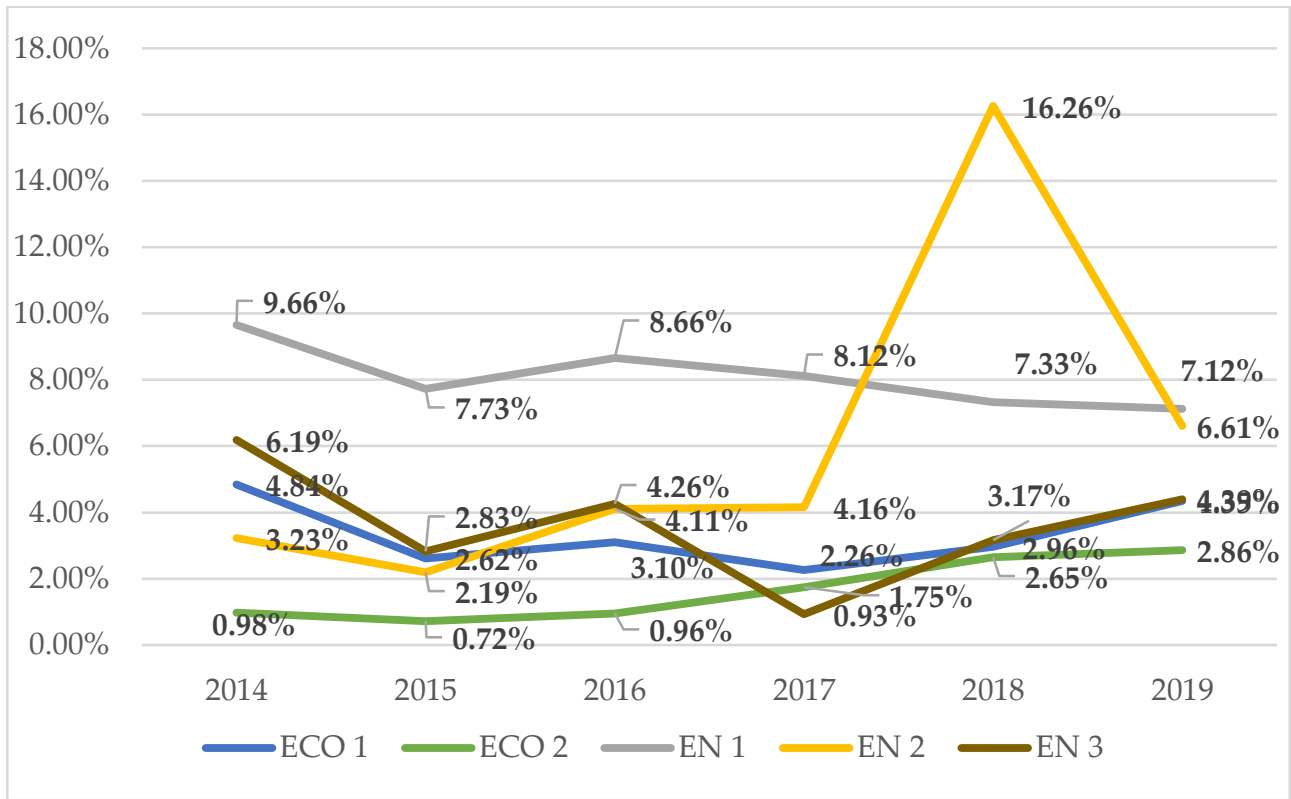

Figure 4. ROS at the surveyed research institutes in 2014-2019. Source: own compilation based on the financial statements.

Positive but only average profitability value should be assessed in this context. The best and the most stable results over time were achieved by the largest energy institute. Closely following was the largest ecological institute with a dynamic upward trend in the profitable use of research facilities.

This underlines the dominant role of these units in the market for research services in their respective fields. The other, smaller units, in terms of ROA were also characterized by an upward trend until 2019. Nevertheless, among all five analyzed institutes, only the organic units managed to maintain it, which was related to their lower dependence on orders from industrial companies.

ROE at research institutes ranged from $0.52 \%$ to $16.26 \%$, which meant that 1 PLN of committed financing brought the state as the owner from 0.5 PL cent to almost $17 \mathrm{PL}$ cent of net profit (on average maximum 10 PL cent of net profit). Such profitability can be considered as quite good, taking into account market alternatives giving 3-6\% return on investment in that period. Beneficial and increasing in time profitability levels were, in this case, boasted by ecological institutes and EN 2 (also to a large extent due to low equity).

The energy institute dealing with production automation, originally mining production, was the weakest in the comparison.

ROS, which illustrates the process profitability of the institutes, was between $0.72 \%$ and $4.26 \%$ in four of the five units by 2017. During this period, the largest energy institute, EN 1, stood out in terms of ROS, with sales generating about 8-9 PL cents per 1 PLN of revenue. After 2017, profitability in the other institutes also increased; however, the rate of growth was halted in 2019 due to the pandemic.

In addition to the classical measures of profitability, the article also decided to calculate the employment profitability. For this purpose, only the financial result from sales was taken into account, which is the difference between sales revenue (subsidy + other revenue) and operating costs. The operating financial result calculated in this way was divided by the number of employees. This made it possible to calculate and compare the absolute profitability of research and development employees who are carriers of knowledge and creators of technology. Table 4 presents the results of these calculations. 
Table 4. Sales profit per employee of surveyed research institutes from 2014 to 2019.

\begin{tabular}{ccccccc}
\hline \multirow{2}{*}{ Institute } & \multicolumn{7}{c}{ Years } \\
\cline { 2 - 7 } & $\mathbf{2 0 1 4}$ & $\mathbf{2 0 1 5}$ & $\mathbf{2 0 1 6}$ & $\mathbf{2 0 1 7}$ & $\mathbf{2 0 1 8}$ & $\mathbf{2 0 1 9}$ \\
\cline { 2 - 6 } & \multicolumn{7}{c}{ [PLN] } \\
\hline ECO 1 & 103,078 & 51,116 & 60,486 & 83,206 & 72,254 & 127,904 \\
ECO 2 & $-34,684$ & -2471 & -5480 & 141,438 & -3253 & -7121 \\
EN 1 & 27,753 & 18,096 & 6897 & 5242 & 19,652 & 29,296 \\
EN 2 & $-83,918$ & $-91,442$ & $-90,953$ & $-74,740$ & $-18,818$ & 9260 \\
EN 3 & $-11,687$ & $-15,964$ & $-13,505$ & -4000 & -6627 & -8494 \\
\hline
\end{tabular}

Source: own elaboration based on financial statements.

For clarification, it should also be added that all the relative indicators presented in the following section refer to scientific research employees, because it was assumed that they generate income/effects from the basic activity of the entity. This argumentation is also supported by the fact that funds allocated under research subsidies from the state budget and the evaluation of scientific quality only concern this group of employees.

The highest employment profitability was reported by the largest environmental institute. It was closely followed by the largest energy institute. Both units achieved positive values of the calculated indicator throughout the period. The worst performer was EN 3, which showed employment inefficiency from 2019 to 2024. The reported loss decreased over time, indicating a slight improvement in this area. Significant losses were also experienced by staff employed in EN 2. Unstable and negative levels of employment profitability were shown by ECO 2 . The indicated fluctuations and negative observations were largely due to intensive revenue and cost changes while maintaining a fairly stable level of employment, the key resource of the institutes' intellectual capital. Interestingly, despite the very large number of employees, two group leaders (ECO 1 and ECO 2) managed to achieve very good employment profitability results throughout the period.

In addition, the effectiveness assessment also uses the number of patents filed by individual institutes, treating it as a measurable effect of inventive activity. Table 5 shows this efficiency in relative terms in the form of the total and absolute number of patents per one employee.

Table 5. Total number of patents per one employee in the studied research institutes in the years 2014-2019.

\begin{tabular}{ccccccc}
\hline & \multicolumn{7}{c}{ Years } \\
\cline { 2 - 7 } Institute & $\mathbf{2 0 1 4}$ & $\mathbf{2 0 1 5}$ & $\mathbf{2 0 1 6}$ & $\mathbf{2 0 1 7}$ & $\mathbf{2 0 1 8}$ & $\mathbf{2 0 1 9}$ \\
\cline { 2 - 7 } & \multicolumn{7}{c}{ [Number] } \\
\cline { 2 - 7 } ECO 1 & 0 & 0 & 0 & 0 & 2 & 0 \\
ECO 2 & 0 & 0 & 2 & 0 & 0 & 0 \\
EN 1 & 11 & 10 & 10 & 10 & 14 & 27 \\
EN 2 & 5 & 5 & 4 & 3 & 2 & 2 \\
EN 3 & 10 & 16 & 11 & 13 & 12 & 4 \\
\hline & & \multicolumn{7}{c}{ [Number per One Employee] } \\
ECO 1 & 0.000 & 0.000 & 0.000 & 0.000 & 0.029 & 0.000 \\
ECO 2 & 0.000 & 0.000 & 0.059 & 0.000 & 0.000 & 0.000 \\
EN 1 & 0.039 & 0.036 & 0.036 & 0.036 & 0.050 & 0.097 \\
EN 2 & 0.056 & 0.056 & 0.045 & 0.034 & 0.022 & 0.022 \\
EN 3 & 0.095 & 0.152 & 0.105 & 0.124 & 0.114 & 0.038 \\
\hline
\end{tabular}

Source: own elaboration based on financial statements.

Table 5 shows that environmental institutes practically did not generate patent applications, which results from the specificity of their activities, which are dominated by environmental measurements and assessments that do not directly contribute to the creation of inventions that can be patent protected. 
Among energy institutes, the most patents in relative terms in the period of 2014-2019 generated by EN1 (82). After 2016, the number of reports submitted by this institute clearly increased, which proves the intensive efforts to adapt to the changed legal and evaluation regulations. This allowed EN1 to achieve the best absolute score in 2019. In previous years, EN2 was ahead of EN1 in this respect, being the leader of the presented list. However, it is worth adding that in terms of the total number of patents, the efficiency of the studied institutes is not impressive in relation to the number of employees, which in the case of EN1 exceeds 270 people and EN 100 people. These results correspond to the poor result of the Polish economy in terms of innovation and reflect the partial ineffectiveness of the national innovation system.

\subsection{Innovation of Research Institutes from Employees' Perspective}

In the last research stage, an excerpt from a 2018 survey conducted among employees of research institutes was used. In this survey, employees were asked whether they felt they worked in an institution with high prestige and innovation.

They were also asked whether the unit's authorities initiate external contacts that foster knowledge and technology transfer in domestic and international settings. The results of the answers to these questions obtained from 215 people are presented in Figures 5-7.

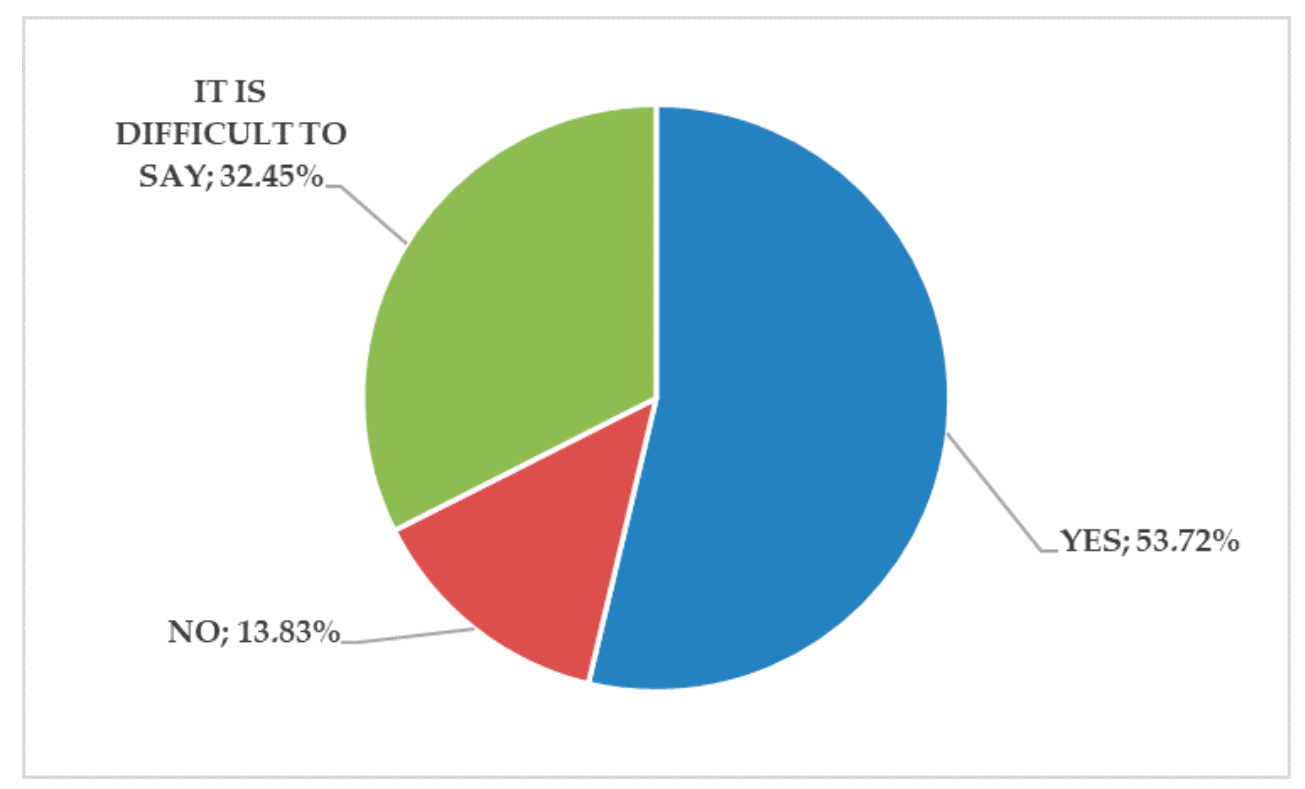

Figure 5. Distribution of responses to the question about the perception of the institute as a prestigious place to work. Source: own elaboration based on the results of questionnaire surveys.

According to the data presented in the figures, only $53.72 \%$ of the respondents believed that they work in a prestigious place and as many as $13.83 \%$ explicitly declared that the institute is not such a place for them. Moreover, almost $30 \%$, of the respondents stated that the institutes where they work are not innovative and as many as $25 \%$ could not assess the state of innovation of the institute unambiguously. Such results reflect badly on the operation, image and equipment of these units. They may result from underfunding, lack of investment or willingness to act on the part of the authorities. Regardless of the reason, however, they have a negative impact on the public perception of research institutes and are not conducive to establishing business relationships. They also reflect badly on the ability of employees - the carriers of intellectual capital - to identify themselves with the research institution. The convergence of all these factors may weaken the effectiveness and efficiency of research institutes in Poland. Therefore, we can conclude that reform is needed not only in the model of financing and operation, but also the organizational culture with particular emphasis on motivational factors. 


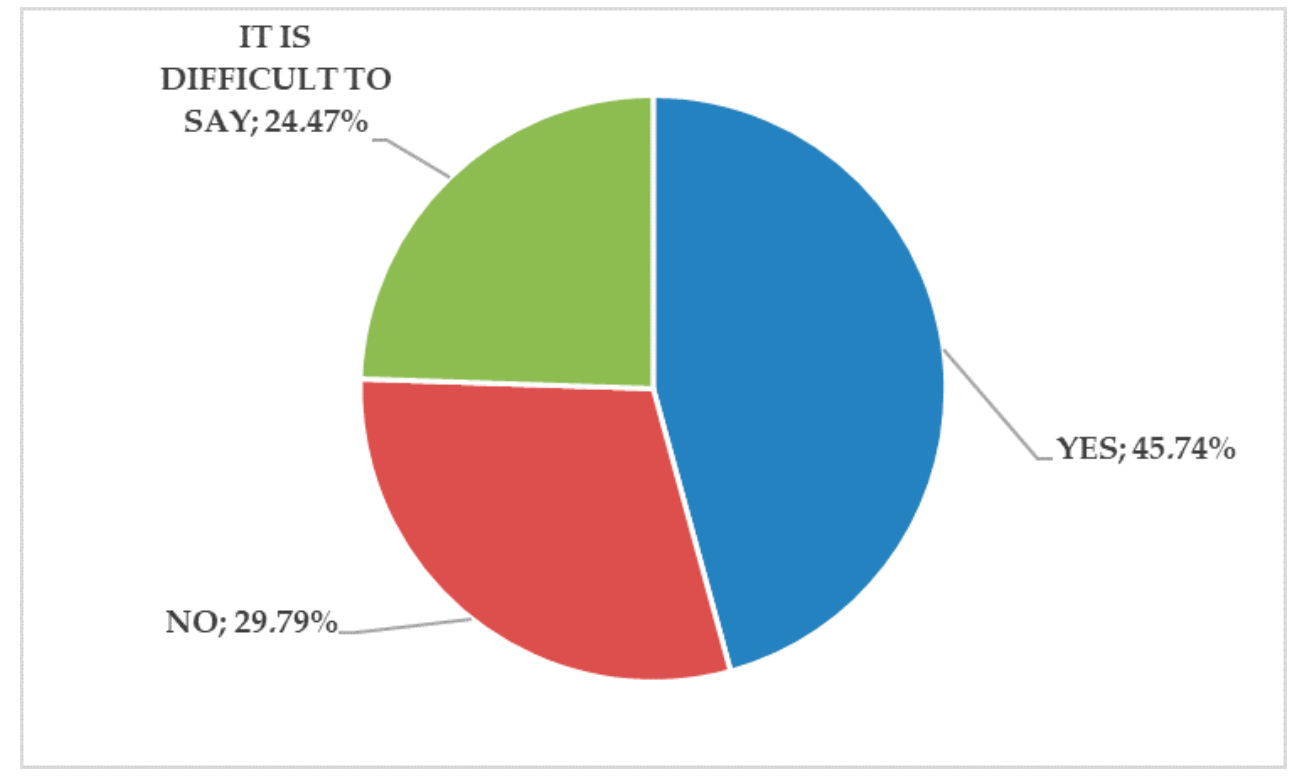

Figure 6. Distribution of responses to the question about the perception of the institute as an innovative place to work. Source: own elaboration based on the results of questionnaire surveys.

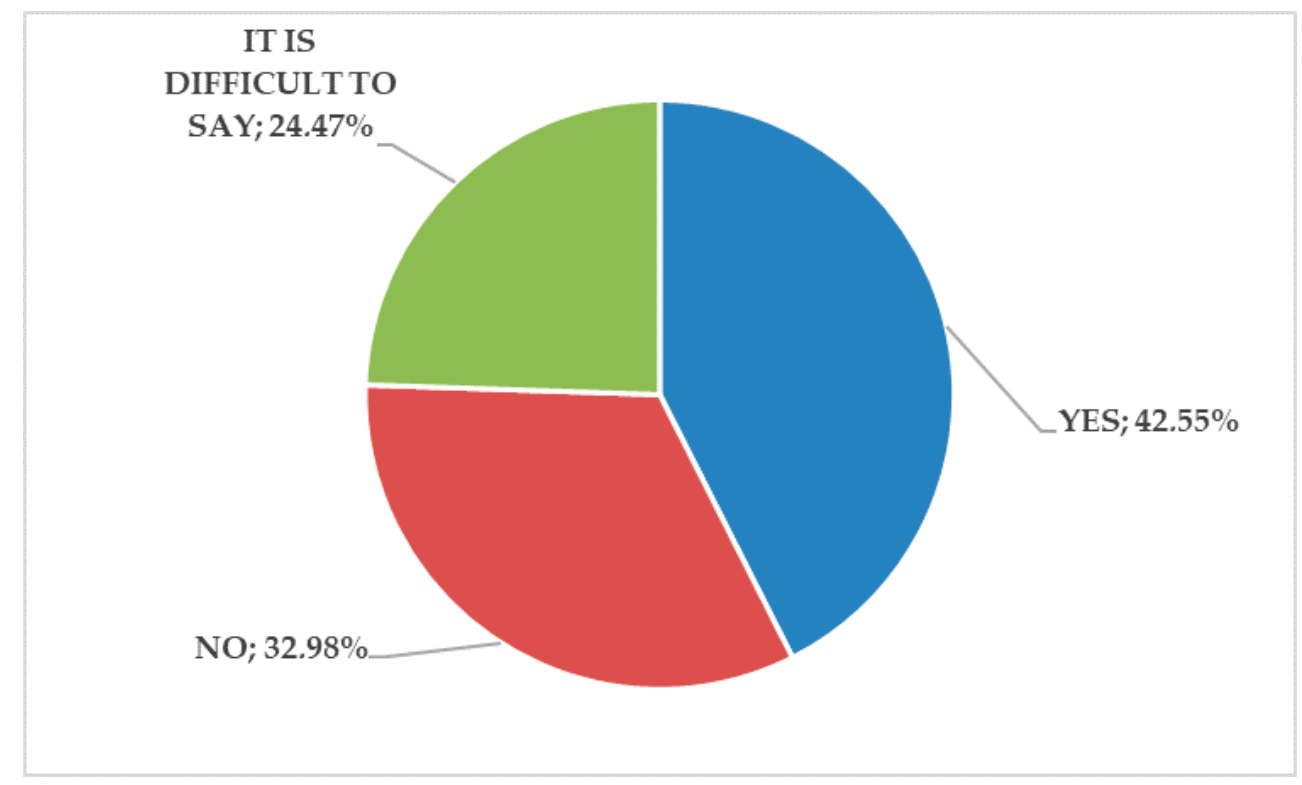

Figure 7. Distribution of responses to the question about initiating external contacts by institute authorities. Source: own elaboration based on the results of questionnaire surveys.

Research also shows a fairly low assessment of the activity of the institutes' authorities in initiating contacts with the socio-economic environment, which is one of the key tasks of these authorities and a necessary condition for starting and deepening business contacts. Nearly a third of the surveyed employees openly declared that directors of research institutes do not engage in obtaining industrial partners and about a quarter are not able to explicitly confirm such involvement (Figure 7).

\section{Conclusions}

\subsection{Summary of Research Results}

The results allow us to conclude that the selected research institutes coped well in the new legislative and legal conditions. None of them experienced economic losses. The profitability of assets, equity and sales levels were at an average level and also periodically 
at a high level. The risk associated with the structure of equity was low or acceptable. Thus, the overall economic image of the studied units was positive, both in environmental and energy institutes, directly and indirectly related to declining coal mining.

Nevertheless, it should be emphasized that ecological institutes seemed less determined when striving for revenues from the socio-economic environment than energy institutes more strongly affected by the downturn in the mining sector, which exposes the important role of economic conditions in the financing strategies of scientific units.

Therefore, the above observations justify the statement that energy institutes directly related to hard coal mining in Poland successfully defended themselves against the threats of losing customers and environmental institutes only partially used the opportunities related to the change in the economic situation in the energy sector and environmental protection, mainly focusing on accepting governmental orders.

A detailed analysis of the structure of revenues and changes in operating costs also clearly indicates a strong desire to increase financial independence manifested both in the search for opportunities to increase extra-budgetary revenues and in the reduction of operating costs. In addition, the energy institutes successfully sought to increase the public subsidy by improving the publication and research parameters which drive such subsidies. Such observations confirm the results of previous research, indicating the possibility of improving the efficiency of public entities by changing the funding model, including reducing subsidies from the state budget.

Nevertheless, taking into account the number of patents created in the studied institutes, it is still at a low level. Inventions are not made in ecological institutes at all. In energy institutes, the situation is better, but only in one of the five surveyed entities a significant increase in the number of patent applications can be observed. This proves the partial ineffectiveness of the state's systemic actions aimed at strengthening the innovativeness of the Polish economy.

Narrowing the research perspective to the result executed on the operational level (result on sales), however, revealed some efficiency problems present in smaller research institutes, both in the environmental and energy sectors. In these units, a loss on sales and, consequently, inefficiency in employment was found in the majority of the analyzed research period. Such losses and inefficiencies necessitate taking aggressive measures to enhance effectiveness in the basic area of activity of these institutes, which has already been partially implemented by them and reflected in the decreasing scope of incurred losses.

The conducted analysis also shows that the change in the financing model and statutory orientation of research institutes' activities aimed at intensification of their relations with the socio-economic environment, including international, has also contributed to the increase in financing risk, which manifests itself in high variability of the value of sales revenues, including primarily those obtained from commercial sources. This is due to changing market conditions and the characteristic inconstancy and irregularity of these revenues. In an environment where personnel and infrastructure costs are fixed, such revenue volatility exposes the institutes to a higher risk of loss than would be the case with certain and fixed budgeted revenues.

\subsection{Practical Recommendations for Research Institutes in Poland}

The analysis allows us to conclude that Polish research institutes have been able to adapt to changes in the rules of their operation and, additionally, to changes occurring in the socio-economic environment. This adaptation ability indicates flexibility in operation and good adaptability, which is undoubtedly also characteristic of innovative entities [88,89]. Nevertheless, the analysis shows that the stabilization of revenues and sources of financing was largely conducted through efforts to receive a higher subsidy or/and by soliciting government and local government orders. There was also no significant improvement in the results in the area of inventiveness, which may suggest a low impact of changes on the desired results of innovation [22-25]. Therefore, the science-business relationship still needs improvement. In this regard, the following measures could be recommended: 
- current identification of business needs on the market and better adjustment of the scientific and research offer to them;

- inclusion of the so-called innovation promoters responsible for development and popularization of innovation policy in the process of knowledge and technology transfer [77-79];

- creation and improvement of marketing tailored to the needs of scientific and research institutions;

- maximization of implementation activities as a real dimension of knowledge transfer and diffusion [98-103];

- internationalization of inventive activity through cooperation with foreign scientific and business entities [95-97].

An effective way to promote the knowledge and experience of the institutes could certainly be their involvement in the process of creating open innovation by popularizing knowledge and achievements among children, young people, local communities and entrepreneurs. This is all the more so as previous research confirms the effectiveness of such activities [7-10]. In this context, parallel productive efforts should also be made to improve the image of research institutes, which should be perceived as prestigious and innovative workplaces primarily by the employees themselves.

It seems that the main problem of the poor activity of research institutes in favour of open innovation is their hermetic nature, the lack of openness to contacts with the socio-economic environment and the low level of interaction with enterprises and the local community. This activity is also not conducive to the described method of financing, i.e., high dependence on the budget subsidy, not motivating individuals to go beyond the internal structure. With the above in mind, two groups of recommendations should be formulated, addressed to institute managers and government decision-makers coordinating their activities, respectively.

Managers should activate marketing channels to increase the number and intensity of contacts with enterprises and local government representatives, who may also be important support for increasing contacts in the national innovation system. They should also make every effort to ensure that industrial orders are carried out at the highest technological and formal level, because the high quality of the services provided guarantees obtaining further orders and strengthening business relations. The visibility and recognition of research institutes and the effects of their activities should also be increased.

Government decision-makers, by making changes to the rules of operation of research institutes, have already taken steps to increase the innovativeness of these entities and their business and social opening. Nevertheless, from the point of view of the results so far, it can be concluded that their efforts have not yet brought the desired effect. In this respect, therefore, the performance of the institutes should be monitored more intensively and linked more closely to the final level of funding. This will undoubtedly be conducive to the current system of evaluation of scientific research activity based on the rules of competition. It would also be good to strengthen real cooperation between the institute and the coordinating ministry, which would also certainly stimulate open innovation.

At the same time, it is worth noting that in order to create open innovation, cooperation within successive economic helices is of key importance. However, both groups of the above-mentioned decision-makers must understand that, in this case, it is about real cooperation, not formal cooperation measured by the number of concluded agreements and contracts, which, as mentioned, is the most common form of cooperation as part of open innovations in Poland. This requires a certain self-awareness, a critical assessment of the activities carried out so far for innovation and changes in the culture of the organisation and the rules of shaping relations with the socio-economic environment. Unfortunately, these are not easy challenges. Nevertheless, they must be undertaken as soon as possible to reduce Poland's innovation gap with developing countries, including most European Union countries. 


\subsection{Reference to Existing Research and Literature Studies}

The case studies presented in this article refer to the role of scientific and research institutions in the transfer and diffusion of innovation. They also refer to the presentation of the mechanisms of implementation of the systemic innovation policy and the operation of the national innovation system in Poland. The analyses, therefore, complement the previous studies with practical aspects of the above-mentioned research areas.

Moreover, they refer to less frequently described economic and financial issues which have a significant impact on the effectiveness, efficiency and scope of innovation creation, including open innovation.

The cited research results confirm the possibility of effective change in the way public scientific entities operate [21]. They also support the assumption of the important role of the state in the transfer of knowledge and technology implemented within the framework of innovation policy, which guarantees greater openness of the innovation process and differentiation of the objectives of innovation activities [68-74].

The possibility of obtaining revenues from sources other than the budget subsidy also confirms the interest of business in the effects of R\&D [18-20]. This is because these revenues effectively supplemented the sources of financing of the institutes' activities. The intervention of the state to activate scientific units and, thus, its role as a creator of innovation policy was fully justified [60-73]. Thus, it can be concluded that the state can and is an active participant in the process of strengthening knowledge and technology transfer to the economy.

Nevertheless, the remaining unresolved and difficult issue is the very limited financial capacity of state scientific units, which was also exposed by the employees of the institutes in the evaluation of the prestige and innovativeness of these units. Public finances, especially in developing economies, have limited sufficiency, which was and is a significant barrier to the creation of innovation [28-30]. This imbalance of commercial and state potential can also seriously limit the sharing of knowledge and technology [80-85] and inhibit the development of open innovation useful for the development of local and regional communities [31-37]. For this reason, the recommendation would be to raise awareness of the role of sharing intellectual resources through selected elements of innovation policy and the national innovation system, especially since such a policy-according to the literature-promotes social and economic development [11,12].

The complexity of the national innovation system makes it difficult to analyze the reasons for its ineffectiveness. They can lie both on the side of the entities creating the knowledge and innovation flow network. It may also result from insufficient transfer of knowledge and technology between individuals. Finally, it may also result from the low level of knowledge and technology in a given economy, which is not conducive to its effective dispersion [120-122]. However, it should be clearly emphasized that an effective national innovation network has a positive effect on open innovation and contributes to its development, which, in turn, results in an improvement in the quality of life and the development of civilization and economic development.

\subsection{Research Limitations and Proposal for Further Research Directions}

The research presented in this paper deals with a certain research period, a very specific geographical location and selected case studies. The circumstances cited herein constitute the main research limitation and result from the adopted methodology. Therefore, they do not allow generalization of the results and statements.

Nevertheless, the in-depth research and calculations are a detailed source of knowledge on economic and financial aspects of the functioning of institutions participating in the transfer and diffusion of knowledge in the economy. They can also be used as an inspiration to repeat the research in other local and regional conditions, becoming, at the same time, the basis for international comparisons or recommendations. Therefore, this research carries a significant diagnostic, cognitive and methodical value. 
In view of the shortcomings and deficiencies found in the activity of the institutes, further research should be directed towards improving the scientific and research offer of the institutes and tightening the relations between business and science, as well as strengthening further links of economic helices [4-6], by including local communities and environmental organizations in already existing business systems. An interesting and practical issue is also the implementation in scientific and research institutes of business marketing tools adapted to the specifics of scientific and research activities.

Funding: This research was funded by Silesian University of Technology, Faculty of Organization and Management, Department of Economics and Computer Science, grant number 13/010/BK_21/0057.

Institutional Review Board Statement: Not applicable.

Informed Consent Statement: Not applicable.

Data Availability Statement: http:/ / bip.eu (accessed on 20 June 2021).

Conflicts of Interest: The author declares no conflict of interest.

\section{Appendix A}

Table A1. A detailed description of the activities of the research institutes described in the article.

Institute

(1) conducting research and development works in the fields of: exact and natural sciences, engineering and technical sciences and agricultural sciences, adapting the results of these scientific research and development works to the needs of practice and participation in the implementation of the results of these research and works, in particular: disseminating the results of research and development works carried out by the Institute, including through publishing activities and sales of the Institute's publications; technical research and analysis; compiling of opinions and expertise in the field of research and development works carried out by the Institute; cartographic activity, development of thematic maps, also based on the research conducted by the Institute; activities of non-public libraries; collecting, processing and sharing data in the field of business activities, including running and developing databases; activities supporting the government administration in the implementation of obligations resulting from membership in the European Union and from agreements on environmental protection signed and ratified by the Republic of Poland; activities supporting public administration in the field of environmental protection; conducting educational and popularising activities, including organising training courses, seminars, conferences, symposia;

(2) development of scientific and technical foundations, including methodologies in research fields: comprehensive environmental studies, including processes and effects of degradation; environmental policy and environmental protection strategies, programmmes and plans; counteracting climate change and adapting to the effects of these changes; air protection against pollution; protection and restoration of water resources; protection and restoration of the biologically active surface of the earth; conservation of living nature resources and ecosystem services; landscape protection; noise protection; management of chemicals in the environment; environmental technologies;

(3) participation in the implementation of the results of scientific research and development works in the field of: environmental monitoring and assessment of its condition and changes taking place in it; environmental quality standards, norms and indicators; pollutant emission factors; validation of research, measurement and apparatus calibration methods; economic, legal and social foundations of environmental protection; systems and methods for documenting and forecasting changes in the environment; systems and methods of documenting protected nature resources; environmental adaptation programmes to forecast changes in the environment; strategic environmental impact assessments and environmental impact assessments for planned projects, as well as ecological reviews and post-implementation analyses; environmental impact assessments of chemical substances, preparations and products; environmental and health risk assessment; use of the principles of environmental protection and natural resources in spatial planning; designing methods and techniques for environmental protection, revitalisation and remediation.

(1) activities in the field of scientific research and development works of the institute include in particular the following issues: sustainable development; environmental protection and management of its resources; eco-innovation support tools, including environmental technology verification; research methodology in the field of environmental protection and engineering; the quality and condition of the environment, in particular in relation to highly urbanized and industrialized areas and areas of ecological threats; modern methods of environmental quality management; (2) institute: conducts activities in the field of social communication and education for sustainable development; organises and runs the secretariat of the Competition of the Minister of the Environment 'Polish Ecology Leader'; conducts educational and training activities for the development of scientific, research and technical and engineering and technical staff of research institutions; may conduct other forms of education, including postgraduate studies, training and additional training courses; cooperates with scientific and research departments and with other entities; compiles expert opinions, opinions and assessments regarding the state of the environment within the scope of the Institute's activity; may undertake activities aimed at promoting and disseminating the results of research and development works; performs other tasks ordered by the supervisory body; conducts the activities referred to in Article 2(4) of the Act, including the rental and lease of land or premises, the provision of transport, printing and photocopying services. 
Table A1. Cont.

Institute

EN 1

(1) conducting research, development and innovative implementation works concerning: safety in industry, protection of crews and the work environment; technologies for the excavation, enrichment and processing of minerals and improvement of the efficiency of the mining industry; clean coal technologies; efficient production and use of energy; environmental protection; development and implementation of environmental protection technologies and equipment materials and products for special applications; management of mineral resources, surface water, waste; underground, land and hydrotechnical construction; local and regional development, taking into account the problems arising from the social and economic effects of industrial restructuring;

(2) adapting the results of research and development work to the needs of practice, in particular by: developing, testing and validating new products, processes and services; preparation of projects, plans and documentation for the creation of new products, processes and services; development of prototypes and implementation of pilot and demonstration projects; scientific and technical consultancy; engineering activities and related technical consultancy;

(3) performing tasks particularly important for the planning and implementation of state policy, necessary to ensure energy and public security and environmental protection, including: providing substantive bases for the decision-making process of state administration bodies in the field of industry and environmental protection; taking actions to increase energy and public security; identification and reduction of environmental hazards; monitoring and preventing the effects of phenomena and events that may pose a public threat;

(4) improvement of methods of scientific research and development works.

(1) conducting scientific research, development, implementation and innovative works concerning: improvement of thermochemical conversion processes of solid fuels for the power industry and the chemical industry in the conditions of energy transformation; development of new technological processes in the field of safe processing of solid fuels and the use of products derived from these processes; operation of commercial, industrial and heating boilers with fuel-air-fumes system installations; development of future technologies for the production and use of energy from RES to reduce the carbon footprint of energy carriers and products; implementation of $\mathrm{CO}_{2}$ removal and use technologies; development of RES energy storage methods with the use of chemical processes and syntheses; improving the technology of obtaining and processing hydrogen for the production of direct energy carriers, fuels and chemicals, along with the methods of hydrogen quality assessment; improvement of unit processes accompanying the production of biomethane from biogas plants; development of waste and by-products management technologies in accordance with the principles of the circular economy and the development of raw material recycling methods; improvement of thermal waste recovery processes; implementation of technological, technical and system measures to reduce and prevent the phenomenon of 'low emissions'; development and improvement of technologies for the production of low emission solid fuels for the municipal economy; improvement of the structure of boilers fired with solid fuels for the purposes of individual heating and municipal heating; improvement of coke production technology and increasing the efficiency of technological and environmental safety of coking plants for the decarbonisation of this sector; improving the technology of processing carbon derivatives; construction, heating and regulation of coke oven batteries, as well as the development of new technologies for the construction and extension of coke oven battery life.

(2) performing tasks particularly important for the planning and implementation of state policy, necessary to ensure energy security and environmental protection; taking actions to increase energy, environmental and public security; identification and implementation of activities leading to the reduction/elimination of environmental threats related to the industrial production of the fuel and energy sector; support for state and local government administration bodies in the identification and implementation of activities leading to the reduction/elimination of environmental threats related to the use of fossil and processed solid fuels; monitoring and preventing the effects of phenomena and events that may pose a public threat, related to the operation of the fuel and energy industry; coordination of the existing and prospective area of use of solid fuels for the needs of individual heating for the identification and elimination of phenomena and processes that may cause environmental hazards; supporting the standardisation activity of the Polish Committee for Standardization through the work of technical committees; implementation of specialised statistical surveys in the coke industry; improving the methods of conducting scientific research and development works.

(1) conducting research and development works in the field of: mechanisation of mining and processing processes in mining, including: development of mechanisation systems for technological processes in mining and development of technical solutions for machines and equipment for mining; automation and robotics of technological processes in mining, including: development of mechatronic systems and development of control systems, diagnostics and monitoring of mechanisation systems; mechanisation of production and transport processes, including: development of technologies for the use of mining excavations and development of drive systems; creating technologies and equipment for environmental protection; improvement of methods of scientific research and development works; conducting laboratory and operational tests in terms of functionality, reliability, ergonomics, work safety and environmental protection;

(2) adapting the results of research and development work to the needs of practice, including: production of prototypes and patterns as well as provision of research services; processing of data related to the conducted research and development works; engineering activities and related technical consultancy; development of scientific and technical expertise; other professional, scientific and technical activities;

(3) implementation of the results of scientific research and development works, including: creating product and process documentation, developing software and providing scientific and development services; production of machinery for mining and excavation and construction related to the research and development work carried out by the entity. 


\section{References}

1. Barandiaran-Irastorza, X.; Peña-Fernández, S.; Unceta-Satrústegui, A. The archipelago of cultural and creative industries: A case study of the basque country. Economies 2020, 8, 21. [CrossRef]

2. Zhao, S.; Zhang, C.; Qi, J. The key factors driving the development of new towns by mother cities and regions: Evidence from China. ISPRS Int. J. Geo Inf. 2021, 10, 223. [CrossRef]

3. Stoica, O.; Roman, A.; Rusu, V.D. The nexus between entrepreneurship and economic growth: A comparative analysis on groups of countries. Sustainability 2020, 12, 1186. [CrossRef]

4. Supriyadi, R.Y. Local economic development and triple helix: Lesson learned from role of universities in higher education town of Jatinangor, West Java, Indonesia. Procedia Soc. Behav. Sci. 2012, 52, 299-306. [CrossRef]

5. Maruccia, Y.; Solazzo, G.; Del Vecchio, P.; Passiante, G. Evidence from network analysis application to innovation systems and quintuple helix. Technol. Forecast. Soc. Chang. 2020, 161, 120306. [CrossRef]

6. Hernández-Trasobares, A.; Murillo-Luna, J.L. The effect of triple helix cooperation on business innovation: The case of Spain. Technol. Forecast. Soc. Chang. 2020, 161, 120296. [CrossRef]

7. Capaldo, A.; Petruzzelli, A.M. Partner geographic and organizational proximity and the innovative performance of knowledgecreating alliances. Eur. Manag. Rev. 2014, 11, 63-84. [CrossRef]

8. Petruzzelli, A.M. The impact of technological relatedness, prior ties, and geographical distance on university-industry collaborations: A joint-patent analysis. Technovation 2011, 31, 309-319. [CrossRef]

9. Mgendi, G.; Shiping, M.; Xiang, C. A review of agricultural technology transfer in Africa: Lessons from Japan and China case projects in Tanzania and Kenya. Sustainability 2019, 11, 6598. [CrossRef]

10. Schepis, D.; Purchase, S.; Butler, B. Facilitating open innovation processes through network orchestration mechanisms. Ind. Mark. Manag. 2021, 93, 270-280. [CrossRef]

11. Maskell, P.; Malmberg, A. The competitiveness of firms and regions: 'Ubiquitification' and the importance of localized learning Eur. Urban. Reg. Stud. 1999, 6, 9-25. [CrossRef]

12. Amin, A.; Cohendet, P. Geographies of knowledge formation in firms. Ind. Innov. 2005, 12, 465-486. [CrossRef]

13. Li, C.; Rausell Köster, P. Exploring the opportunities and challenges of european design policy to enable innovation. the case of designscapes project. Sustainability 2020, 12, 5132. [CrossRef]

14. Krishna, V.V. Universities in the national innovation systems: Emerging innovation landscapes in Asia-Pacific. J. Open Innov. Technol. Mark. Complex. 2019, 5, 43. [CrossRef]

15. Perkmann, M.; Tartari, V.; McKelvey, M.; Autio, E.; Broström, A.; D’este, P.; Fini, R.; Geuna, A.; Grimaldi, R.; Hughes, A.; et al. Academic engagement and commercialisation: A review of the literature on university-industry relations. Res. Policy 2013, 42 , 423-442. [CrossRef]

16. West, J.; Gallagher, S. Challenges of open innovation: The paradox of firm investment in open-sourcesoftware. RED Manag. 2006, 36, 319-331.

17. Gassmann, D.O.; Enkel, E.; Chesbrough, H. The future of open innovation. RD Manag. 2010, 40, 213-221. [CrossRef]

18. Lee, Y.H.; Kim, H.K. Financial support and university performance in Korea universities: A panel data approach. Sustainability 2019, 11, 5871. [CrossRef]

19. Lee, Y.-H.; Kim, K.-S.; Lee, K.-H. The effect of tuition fee constraints on financial management: Evidence from Korean Private Universities. Sustainability 2020, 12, 5066. [CrossRef]

20. Leslie, L.L.; Rhoades, G. Rising administrative costs: Seeking explanations. J. High. Educ. 1995, 66, 187-212. [CrossRef]

21. Caruana, J.; Brusca, I.; Caperchione, E.; Cohen, S.; Manes Rossi, F. (Eds.) Financial Sustainability of Public Sector Entities: The Relevance of Accounting Frameworks; Palgrave Macmillan: London, UK, 2019.

22. Miłek, D. Ocena innowacyjności polskiej gospodarki na tle krajów Unii Europejskiej. Nierówności Społeczne Wzrost Gospod. 2019, 59. [CrossRef]

23. Available online: https:/ / ec.europa.eu/growth/industry/policy/innovation/scoreboards_en (accessed on 30 April 2021).

24. Available online: https://www.nik.gov.pl/aktualnosci/nik-o-gospodarce-finansowej-instytutow-badawczych.html (accessed on 30 April 2021).

25. Available online: https://www.nik.gov.pl/aktualnosci/nik-o-instytutach-badawczych.html (accessed on 30 April 2021).

26. Yun, J.J.; Zhao, X.; Jung, K.; Yigitcanlar, T. The culture for open innovation dynamics. Sustainability 2020, 12, 5076. [CrossRef]

27. Zahran, Y.; Kassem, H.S.; Naba, S.M.; Alotaibi, B.A. Shifting from fragmentation to integration: A proposed framework for strengthening agricultural knowledge and innovation system in Egypt. Sustainability 2020, 12, 5131. [CrossRef]

28. Weber, K.M.; Rohracher, H. Legitimizing research, technology and innovation policies for transformativechange: Combining insights from innovation systems and multi-level perspective in a comprehensive'failures' framework. Res. Policy 2012, 41, 1037-1047. [CrossRef]

29. Audretsch, D.B.; Belitski, M. The role of R\&D and knowledge spillovers in innovation and productivity. Eur. Econ. Rev. 2020, $123,103391$.

30. Cabral, B.P.; Lage de Sousa, F.; Canêdo-Pinheiro, M. Assessing the impacts of innovation barriers: A qualitative analysis of Brazil's natural resources industry. Resour. Policy 2020, 68, 101736. [CrossRef]

31. Bacon, E.; Williams, M.D.; Davies, G.H. Recipes for success: Conditions for knowledge transfer across open innovation ecosystems. Int. J. Inf. Manag. 2019, 49, 377-387. [CrossRef] 
32. Corte, V.D. Innovation through coopetition: Future directions and new challenges. J. Open Innov. Technol. Mark. Complex. 2018, 4, 47. [CrossRef]

33. Rauter, R.; Globocnik, D.; Baumgartner, R.J. Open innovation and its effects on economic and sustainability innovation performance. J. Innov. Knowl. 2019, 4, 226-233. [CrossRef]

34. Behnam, S.; Cagliano, R.; Grijalvo, M. How should firms reconcile their open innovation capabilities for incorporating external actors in innovations aimed at sustainable development? J. Clean. Prod. 2018, 170, 950-965. [CrossRef]

35. Dieguez, T.; Ferreira, L.P.; Silva, S.J.G.; Tjahjono, B. Open innovation and sustainable development through industry-Academia collaboration: A case study of automotive sector. Procedia Manuf. 2020, 51, 1773-1778. [CrossRef]

36. Kramarz, M.; Knop, L.; Przybylska, E.; Dohn, K. Stakeholders of the Multimodal Freight Transport Ecosystem in Polish-CzechSlovak Cross-Border Area. Energies 2021, 14, 2242. [CrossRef]

37. Janik, A.; Ryszko, A.; Szafraniec, M. Greenhouse Gases and Circular Economy Issues in Sustainability Reports from the Energy Sector in the European Union. Energies 2020, 13, 5993. [CrossRef]

38. Kennedy, S.; Whiteman, G.; van den Ende, J. Radical innovation for sustainability: The power of strategy and open innovation. Long Range Plan. 2017, 50, 712-725. [CrossRef]

39. Hamdani, J.; Wirawan, C. Open innovation implementation to sustain indonesian SMEs. Procedia Econ. Financ. 2012, 4, 223-233. [CrossRef]

40. Yun, J.J.; Liu, Z. Micro- and macro-dynamics of open innovation with a quadruple-helix model. Sustainability 2019, 11, 3301. [CrossRef]

41. Elmustapha, H.; Hoppe, T. Challenges and opportunities of business models in sustainable transitions: Evidence from solar energy niche development in lebanon. Energies 2020, 13, 670. [CrossRef]

42. Enkel, E.; Bader, K.; Tidd, J. How to balance open and closed innovation: Strategy and culture as influencing factors. Knowl. Enterp. 2013, 23, 87-104.

43. Chesbrough, H.W.; Garman, A.R. Otwarta innowacyjność: Recepta na trudne czasy. Harv. Bus. Rev. Pol. $2019,11,288-302$.

44. Chesbrough, H.W. Open Innovation: The New Imperative for Creating and Profiting from Technology; Harvard Business School Press: Boston, MA, USA, 2003.

45. Robbins, P.; O'Gorman, C.; Huff, A.; Moeslein, K. Multidexterity-A new metaphor for open innovation. J. Open Innov. Technol. Mark. Complex. 2021, 7, 99. [CrossRef]

46. Bellantuono, N.; Pontrandolfo, P.; Scozzi, B. Measuring the openness of innovation. Sustainability 2021, 13, 2205. [CrossRef]

47. Ryu, D.; Baek, K.H.; Yoon, J. Open Innovation with relational capital, technological innovation capital, and international performance in SMEs. Sustainability 2021, 13, 3418. [CrossRef]

48. Bril, A.; Kalinina, O.; Valebnikova, O.; Valebnikova, N.; Camastral, M.; Shustov, D.; Ostrovskaya, N. Improving personnel anagement by organizational projects: Implications for open innovation. J. Open Innov. Technol. Mark. Complex. 2021, 7, 105. [CrossRef]

49. Mathrani, S.; Edwards, B. Knowledge-sharing strategies in distributed collaborative product development. J. Open Innov. Technol. Mark. Complex. 2020, 6, 194. [CrossRef]

50. Leitão, J.; Pereira, D.; Brito, S.D. Inbound and outbound practices of open innovation and eco-innovation: Contrasting bioeconomy and non-bioeconomy firms. J. Open Innov. Technol. Mark. Complex. 2020, 6, 145. [CrossRef]

51. Chesbrough, H. The Era of Open Innovation. MIT Sloan Manag. Rev. 2003, 44, 35-42.

52. Enkel, E.; Gassmann, O.; Chesbrough, H. Open R\&D and open innovation: Exploring the phenomenon. RD Manag. 2009, 39, 311-316.

53. Wallin, M.W.; Von Krogh, G. Organizing for open innovation: Focus on the integration of knowledge. Organ. Dyn. 2010, 39, 145-154. [CrossRef]

54. Leitão, J. Open Innovation Business Modeling; Springer: Berlin/Heidelberg, Germany, 2019.

55. Silva, M.J.M.; Leitão, J. Cooperation in innovation practices among firms in Portugal: Do external partners stimulate innovative advances? Int. J. Entrep. Small Bus. 2009, 7. [CrossRef]

56. Sopińska, A.; Dziurski, P. Strategie współpracy w otwartych innowacjach w Polsce. Organ. i Kier. 2018, 4, 147-158.

57. Sopińska, A.; Mierzejewska, W. Wybór partnerów do tworzenia innowacji w modelu otwartym. Studia Oeconomica Posnaniensia 2017, 5, 123-141. [CrossRef]

58. Pichlak, M.; Szromek, A.R. Eco-Innovation, Sustainability and Business Model Innovation by Open Innovation Dynamics. J. Open Innov. Technol. Mark. Complex. 2021, 7, 149. [CrossRef]

59. Ergas, H. Does technology policy matter? In Technology and Global Industry: Companies and Nations in the World Economy; Guile, B.R., Brooks, H., Eds.; The National Academies Press: Washington, DC, USA, 1987.

60. Mazzucato, M. Mission-oriented innovation policies: Challenges and opportunities. Ind. Corp. Chang. 2018, $27,803-815$. [CrossRef]

61. Wanzenböck, I.; Frenken, K. The subsidiarity principle in innovation policy for societal challenges. Glob. Transit. 2020, 2, 51-59. [CrossRef]

62. Tani, M.; Papaluca, O.; Sasso, P. The System thinking perspective in the open-innovation research: A systematic review. J. Open Innov. Technol. Mark. Complex. 2018, 4, 38. [CrossRef] 
63. Do, M.; Jung, H. The socio-economic benefits of sharing economy: Colleague-based carpooling service in Korea. J. Open Innov. Technol. Mark. Complex. 2018, 4, 40. [CrossRef]

64. Gabriel, C.; Kirkwood, J. Business models for model businesses: Lessons from renewable energy entrepreneurs in developing countries. Energy Policy 2016, 95, 336-349. [CrossRef]

65. Cunningham, S.W.; Werker, C. Proximity and collaboration in European nanotechnology. Pap. Reg. Sci. 2012, 91, 723-742. [CrossRef]

66. Werker, C.; Ooms, W.; Caniels, M.C. Personal and related kinds of proximity driving collaborations: A multi-case study of Dutch nanotechnology researchers. Springerplus 2016, 5, 1751. [CrossRef] [PubMed]

67. Caniëls, M.C.J.; Kronenberg, K.; Werker, C. Conceptualizing proximity in research collaborations between universities and firms. In The Social Dynamics of Innovation Networks; Rutten, R., Benneworth, P., Irawati, D., Boekema, F., Eds.; Routledge: Abingdon, UK, 2014.

68. Ediquist, C. Systems of Innovation: Technologies, Institutions and Organisations; Pinter: London, UK, 1997.

69. Freeman, C. Continental, national and sub-national innovation systems-Complementarity and economic growth. Res. Policy 2002, 31, 191-211. [CrossRef]

70. Freeman, C. Technology Policy and Economic Performance: Lessons from Japan; Pinter: London, UK, 1987.

71. Krishna, V.V.; Sha, S.P. Building science community by attracting global talents: The case of Singapore Biopolis. Sci. Technol. Soc. 2015, 20, 389-413. [CrossRef]

72. Loos, T.K.; Hoppe, M.; Dzomeku, B.M.; Scheiterle, L. The potential of plantain residues for the ghanaian bioeconomy-Assessing the current fiber value web. Sustainability 2018, 10, 4825. [CrossRef]

73. Lundvall, B.-Å. National Innovation Systems: Toward a Theory of Innovation and Interactive Learning; Pinter: London, UK, 1992.

74. Wong, C.Y.; Hu, M.C.; Shiu, J.W. Collaboration between public research institutes and universities: A study of industrial technology research institute, Taiwan. Sci. Technol. Soc. 2015, 20, 161-181. [CrossRef]

75. Xue, L.; Zhou, L. University-market-government interactions: The case of China. In Search of the Triple Helix: University, Enterprise, Government Interaction in China, Republic of Korea and Poland; IIEP-UNESCO: Paris, France, 2007.

76. Wong, P.K.; Ho, Y.P.; Annette, S. Towards an "Entrepreneurial University" modelto support knowledge-BasedEconomic development: The case of the national university of Singapore. World Dev. 2007, 35, 941-958. [CrossRef]

77. Sergeeva, N.; Zanello, C. Championing and promoting innovation in UK megaprojects. Int. J. Proj. Manag. 2018, 36, 1068-1081. [CrossRef]

78. Rocío Vásquez-Urriago, A.; Barge-Gil, A.; Modrego Rico, A. Science and technology parks and cooperation for innovation: Empirical evidence from Spain. Res. Policy 2016, 45, 137-147. [CrossRef]

79. Evangelista Silva, S.; Venâncio, A.; Gonçalves, C.A. Open innovation in science parks: The role of public policies. Technol. Forecast. Soc. Chang. 2020, 151, 119844. [CrossRef]

80. Omobhude, C.; Chen, S.-H. The roles and measurements of proximity in sustained technology development: A literature review. Sustainability 2019, 11, 224. [CrossRef]

81. Salavisa, I.; Sousa, C.; Fontes, M. Topologies of innovation networks in knowledge-intensive sectors: Sectoral differences in the access to knowledge and complementary assets through formal and informal ties. Technovation 2012, 32, 380-399. [CrossRef]

82. Sousa-Ginel, E.; Franco-Leal, N.; Camelo-Ordaz, C. Knowledge conversion capability and networks as drivers of innovation in Academic Spin-Offs. J. Eng. Technol. Manag. 2021, 59, 101615. [CrossRef]

83. Allena-Ozolina, S.; Bazbauers, G. System dynamics model of research, innovation and education system for efficient use of bio-resources. Energy Procedia 2017, 128, 350-357. [CrossRef]

84. Moica, S.; Socaciu, T.; Rădulescu, E. Model innovation system for economical development using entrepreneurship education. Procedia Econ. Financ. 2012, 3, 521-526. [CrossRef]

85. Ji, H.; Miao, Z. Corporate social responsibility and collaborative innovation: The role of government support. J. Clean. Prod. 2020, 260, 121028. [CrossRef]

86. Nowacki, C.; Monk, A. Ambidexterity in government: The influence of different types of legitimacy on innovation. Res. Policy 2020, 49, 103840. [CrossRef]

87. Moodysson, J.; Jonsson, O. Knowledge collaboration and proximity: The spatial organization of biotech innovation projects. Eur. Urban. Reg. Stud. 2007, 14, 115-131. [CrossRef]

88. Becker, B.A.; Eube, C. Open innovation concept: Integrating universities and business in digital age. J. Open Innov. Technol. Mark. Complex. 2018, 4, 12-16. [CrossRef]

89. Kalantaridis, C.; Küttim, M.; Sousa, C. How to commercialise university-generated knowledge internationally? A comparative analysis of contingent institutional conditions. Technol. Forecast. Soc. Chang. 2017, 123, 35-44. [CrossRef]

90. Abbas, A.; Avdic, A.; Ming, W. University-government collaboration for the generation and commercialization of new knowledge for use in industry. J. Innov. Knowl. 2019, 4, 23-31. [CrossRef]

91. Ustawa z Dnia 30 Kwietnia 2010 r. o instytutach badawczych. Dz.U. 2010 nr 96 poz. 618. Available online: http:/ /isap.sejm.gov. pl/isap.nsf/DocDetails.xsp?id=wdu20100960618 (accessed on 30 April 2021).

92. Prokopczyk, P. Efekty Działalności Instytutów Badawczych; Najwyższa Izba Kontroli: Warszawa, Poland, 2014.

93. Szromek, A.R.; Wolniak, R. Job satisfaction and problems among academic staff in higher education. Sustainability 2020, 12,4865 . [CrossRef] 
94. Bidmon, C.M.; Knab, S. The three roles of business models for socio-technical transitions sebastian Knab. In Proceedings of the XXV ISPIM Conference-Innovation for Sustainable Economy and Society, Dublin, Ireland, 8-11 June 2014.

95. Boschma, R. Proximity and innovation: A critical assessment. Reg. Stud. 2005, 39, 61-74. [CrossRef]

96. Scuotto, V.; Del Giudice, M.; Bresciani, S.; Meissner, D. Knowledge-driven preferences in informal inbound open innovation modes. An explorative view on small to medium enterprises. J. Knowl. Manag. 2017, 21, 640-655. [CrossRef]

97. Knoben, J.; Oerlemans, L.A.G. Proximity and inter-organizational collaboration: A literature review. Int. J. Manag. Rev. 2006, 8, 71-89. [CrossRef]

98. Capello, R. Spatial spillovers and regional growth: A cognitive approach. Eur. Plan. Stud. 2009, 17, 639-658. [CrossRef]

99. Möller, K.K.; Halinen, A. Business relationships and networks: Managerial challenge of network era. Ind. Mark. Manag. 1999, 28, 413-427. [CrossRef]

100. Foray, D.; Mowery, D.C.; Nelson, R.R. Public R\&D and social challenges: What lessons from mission R\&D programs? Res. Policy 2012, 41, 1697-1702.

101. Cheslock, J.J.; Gianneschi, M. Replacing state appropriations with alternative revenue sources: The case of voluntary support. J. High. Educ. 2008, 79, 208-229. [CrossRef]

102. Hearn, J.C.; Lewis, D.R.; Kallsen, L.; Holdsworth, J.A.; Jones, L.M. “Incentives for managed growth": A casestudy of incentivesbased planning and budgeting in a large public research university. J. High. Educ. 2006, 77, 286-316. [CrossRef]

103. Hicks, D. Performance-based university research funding systems. Res. Policy 2016, 41, 251-261. [CrossRef]

104. Jonek-Kowalska, I.; Podgorska, M.; Musiol-Urbanczyk, A.; Wolny, M. Sustainable development and motivation opportunities from the perspective of women in the polish science sector in the light of statistical data and surveys. Eur. Res. Stud. J. 2020, XXIII, 456-473. [CrossRef]

105. Zdonek, I.; Hysa, B.; Zdonek, D. Academic staff in the context of known theories of motivation. Eur. Res. Stud. J. 2021, XXIV, 906-935. [CrossRef]

106. Jonek-Kowalska, I. Systemy Motywacyjne w Instytutach Naukowo-Badawczych. Stan Aktualny i Kierunki Doskonalenia; Wydaw. Politechniki Śląskiej: Gliwice, Poland, 2020.

107. Maciej, W. Analysis of the multiple attribute decision making problem with incomplete information about preferences among the criteria. Mult. Criteria Decis. Mak. 2016, 11, 187-197. [CrossRef]

108. Yin, R.K. Case Study Research: Design and Methods, 4th ed.; Sage: Thousand Oaks, CA, USA, 2009.

109. Feagin, J. A Case for the Case Study; University of North Carolina Press: Chapel Hill, NC, USA, 1991; Available online: https: // uncpress.org/book/9780807843215/a-case-for-the-case-study/ (accessed on 30 April 2021).

110. Jonek-Kowalska, I.; Nawrocki, T. Holistic fuzzy evaluation of operational risk in polish mining enterprises in a long-term and sectoral research perspective. Resour. Policy 2019, 63, 1-11. [CrossRef]

111. Nawrocki, T.; Jonek-Kowalska, I. Assessing operational risk in coal mining enterprises-Internal, industrial and international perspectives. Resour. Policy 2016, 48, 57-69. [CrossRef]

112. Michalak, A.; Nawrocki, T. Analiza porównawcza kosztu kapitału własnego przedsiębiorstw górnictwa węgla kamiennego w ujęciu międzynarodowym. Gosp. Sur. Miner. 2015, 31, 49-72. [CrossRef]

113. Tajduś, A.; Turek, M. The state and conditions of the future functioning of hard coal mining in Poland. Arch. Min. Sci. 2019, 64, 547-559. [CrossRef]

114. Ryszko, A. Interorganizational cooperation, knowledge sharing and technological eco-innovation: The role of proactive environmental strategy-Empirical evidence from Poland. Pol. J. Environ. Stud. 2016, 25, 753-763. [CrossRef]

115. Ryszko, A. Proactive environmental strategy, technological eco-innovation and firm performance-Case of Poland. Sustainability 2016, 8, 156. [CrossRef]

116. Korol, J.; Burchart-Korol, D.; Pichlak, M. Expansion of environmental impact assessment for eco-efficiency evaluation of biocomposites for industrial application. J. Clean. Prod. 2016, 113, 144-152. [CrossRef]

117. Czyżewski, B.; Matuszczak, A.; Polcyn, J.; Smędzik-Ambroży, K.; Staniszewski, J. Deadweight loss in environmental policy: The case of the European Union member states. J. Clean. Prod. 2020, 260, 121064. [CrossRef]

118. Mihajlović, N.I.; Voza, D.; VozaIsidora, D.; Milošević, I.; Pantovic, D. Environmental awareness as a universal European value. Serb. J. Manag. 2016, 11. [CrossRef]

119. Research on Ecological Awareness and Behaviour of Polish Residents in 2020 (Tracking Research). Available online: https: / www. gov.pl/web / klimat/badania-swiadomosci-i-zachowan-ekologiczne-mieszkancow-polski-w-2020-r-badanie-trackingowe (accessed on 30 April 2021).

120. Kowalska-Styczeń, A.; Malarz, K. Noise induced unanimity and disorder in opinion formation. PLoS ONE 2020, 15, e0235313. [CrossRef] [PubMed]

121. Paradowski, K.; Kowalska-Styczeń, A.; Malarz, K. Influence of a range of interaction among agents on effciency and effectiveness of knowledge transfer within an organization. Acta Phys. Pol. A 2018, 133, 1470-1476. [CrossRef]

122. Kowalska-Styczeń, A.; Malarz, K.; Paradowski, K. Model of knowledge transfer within an organization. JASSS J. Artif. Soc. Soc. Simul. 2018, 21, 1-30. [CrossRef] 